\title{
Understanding and Managing Customer Relational Benefits in Services: A Meta-Analysis
}

\author{
Dwayne D. Gremler \\ Bowling Green State University \\ Department of Marketing \\ College of Business \\ Bowling Green, OH 43403 \\ Telephone: +1.419 .372 .0226$ \\ Fax: +1.419 .372 .8062$ \\ gremler@bgsu.edu \\ Yves Van Vaerenbergh \\ KU Leuven \\ Warmoesberg 26 \\ 1000 Brussels, Belgium \\ Telephone: +32.2 .3002212$ \\ Fax: +32.2 .2176464$ \\ yves.vanvaerenbergh@,kuleuven.be \\ Elisabeth C. Brüggen \\ Maastricht University \\ Tongersestraat 53 \\ 6211LM Maastricht, The Netherlands \\ Telephone: +31.43 .3883851$ \\ Fax: +31.43 .3884918$ \\ e.bruggen@maastrichtuniversity.nl \\ Kevin P. Gwinner \\ Kansas State University \\ 2019 Business Building \\ 1301 Lovers Lane \\ Manhattan, KS 66506 \\ Telephone: +1.785 .532 .4382$ \\ Fax: +1.785 .532 .3709$ \\ kgwinner@ksu.edu
}

Accepted for publication in Journal of the Academy of Marketing Science 


\title{
Understanding and Managing Customer Relational Benefits in Services:
}

\section{A Meta-Analysis}

\begin{abstract}
Recent meta-analyses provide clear insights into how service firms can benefit from relationship marketing, whereas investigations of customers' relational benefits (1) are unclear about the absolute and relative strengths by which different relational benefit dimensions induce different customer responses and (2) have not simultaneously examined the various mediating processes (including perceived value, relationship quality, and switching costs) through which relational benefits reportedly affect customer loyalty. To consolidate extant research on the benefits of relationship marketing for customers, this meta-analysis integrates 1242 effect sizes drawn from 235 independent samples across 224 papers disseminated in the past two decades. The results reveal that all three relational benefits affect loyalty, though confidence benefits and social benefits have the strongest effects. Among the three identified mediation paths through which relational benefits influence customer loyalty, the sequential path through perceived value and relationship quality is the strongest. From a service research perspective, this study provides novel empirical generalizations; managerially, the findings suggest that a primary goal for service managers should be strengthening confidence and social benefits.
\end{abstract}

Keywords: Relationship Marketing, Relational Benefits, Customer Loyalty, Meta-Analysis, Confidence, Social Benefits, Special Treatment 
Understanding and managing customer loyalty has always been a top priority for both service researchers and managers. Recent industry reports that signal declining customer loyalty (e.g., Leinbach-Reyhle 2016) make this priority even more critical: In an era in which customers can easily shop around online for the best offer, determining how to increase customer loyalty becomes essential (Kumar and Reinartz 2018). The response to this need, in the form of increased research into customer loyalty, consists of two main literature research streams. The first adopts a firm perspective, examining the benefits to companies of engaging in relationship marketing activities (e.g., Morgan and Hunt 1994; Steinhoff and Palmatier 2016). The second takes a customer perspective, seeking to understand the benefits that customers obtain by being loyal to a service firm (e.g., Gwinner et al. 1998).

The current meta-analytic study examines the second stream and customer relational benefits. Relational benefits ${ }^{1}$ originally were conceptualized as unidimensional (Morgan and Hunt 1994), but Gwinner et al. (1998) conceptualize and empirically validate a multidimensional nature. They propose that customers who remain loyal to an organization gain confidence (i.e., reduced anxiety or uncertainty about a service provider's performance), social (e.g., friendships or personal relationships with firm employees), or special treatment (e.g., better deals, lower prices, faster service) benefits. Although the concept of relational benefits was introduced more than two decades ago, and many studies have investigated it since then (Hult and Ferrell 2012; Zinkhan 2005), several issues continue to limit our understanding of customer relational benefits.

First, we lack a comprehensive overview of the absolute and relative strengths by which different relational benefit dimensions induce different customer responses. For example, Hennig-Thurau et al. (2002) report a stronger effect of confidence benefits on customer

\footnotetext{
${ }^{1}$ Several scholars use the term "relationship benefits" (e.g., Morgan and Hunt 1994; Palmatier et al. 2006; Verma et al. 2016) as a synonym for "relational benefits." Rather than switch terms, we use "relational benefits" throughout.
} 
outcomes, relative to social or special treatment benefits, whereas Meldrum and Kaczynski (2007) find a stronger effect of social benefits. Prior meta-analyses (Palmatier et al. 2006; Verma et al. 2016) often conceptualize relational benefits as a single, general construct, discounting the potentially divergent effects of different relational benefits on customer outcomes. Thus, a metaanalysis that provides empirical generalizations about which specific relational benefit dimensions have the strongest effect can help scholars better understand these marketing instruments and help managers focus their attention on strengthening their offerings.

Second, in prior meta-analyses that have shaped relationship marketing theory (Palmatier et al. 2006; Verma et al. 2016), the authors identify relationship quality as a mediator of the relational benefits-customer loyalty relationship. We propose that another mediating variable (perceived value) should be included in the relationship quality path, along with another mediation path that includes switching costs. On the relationship quality path, research has shown that relational benefits contribute to the perceived value that customers receive from firms (e.g., Martin-Ruiz et al. 2008), which helps strengthen customer-firm relationships and improve customer loyalty (e.g., Gil-Saura et al. 2011; Ruiz-Molina et al. 2015). These studies accordingly suggest that perceived value should be considered when developing and testing nomological frameworks of the outcomes of relational benefits; we propose adding this construct to the relationship quality path. Furthermore, relational benefits might induce switching costs that can drive customer loyalty too (Chang and Chen 2007; Gremler and Gwinner 2015). To date, extant literature has not examined the extent to which these two paths simultaneously drive the connections between relational benefits and customer loyalty, which path has a stronger influence, or how these three mediators relate.

To address these issues, we conduct a meta-analysis to (1) study the absolute and relative strength of confidence, social, and special treatment benefits on various customer responses; (2) 
examine which types of processes—relationship quality, perceived value, and/or switching costs - underlie the links between relational benefits and customer loyalty; and (3) investigate which contingency factors (i.e., type of service, type of market, and timing of study) influence these relationships. By establishing empirical generalizations about the manner in which the various relational benefit components influence responses from the customer's perspective, we extend prior meta-analyses, which consider relational benefits from a firm perspective, define it as a single or general construct, and include relationship quality as the sole mediator between the antecedents and outcome variables (Palmatier et al. 2006; Verma et al. 2016). With this effort, we also accommodate several calls to test the roles of perceived value (Kumar and Reinartz 2016) and switching costs (Pick and Eisend 2014, 2016) in relationship marketing frameworks. Accordingly, we contribute to relationship marketing literature by providing more fine-grained insights into how customers' relational benefits affect customers' responses.

\section{CONCEPTUAL FRAMEWORK}

The conceptual framework that guides this meta-analysis is rooted in research that conceptualizes and tests outcomes of three distinct relational benefits: confidence, social, and special treatment benefits. ${ }^{2}$ This literature stream is rooted in service research, whereby services are defined in the broadest sense, including services with high levels of tangibility (Vargo and Lusch 2004). An overwhelming majority of studies examine relational benefits as antecedents of customer loyalty (e.g., Hennig-Thurau et al. 2002), though Gwinner et al. (1998) originally conceptualized them as a consequence of customers' demonstrations of loyalty. For relational benefits to be provided, customers need to exhibit some level of patronage; experiencing relational benefits from such patronage then reinforces that loyalty (Hennig-Thurau et al. 2002).

\footnotetext{
${ }^{2}$ Over time, additional relational benefits have emerged, including identity-related benefits (Fournier 1998), respect benefits (Chang and Chen 2007), hedonic benefits (Meyer-Waarden et al. 2013), and quality improvement benefits (Sweeney and Webb 2002). However, these additional benefits have not appeared frequently in empirical studies, so we limit our focus to confidence, social, and special treatment benefits.
} 
However, due to a lack of empirical studies that examine relational benefits as consequences of loyalty, we do not discuss this link further.

Similar to prior meta-analyses (Palmatier et al. 2006; Scheer et al. 2015; Watson et al. 2015), we include a construct in our proposed model only if (1) there are at least five effect sizes and (2) a customer response variable can be observed. We group any highly related variables that would be difficult to separate in a composite construct. For example, relationship satisfaction, trust, and commitment are all indicators of the higher-order construct "relationship quality" (De Wulf et al. 2001), and attitudinal loyalty and behavioral loyalty are both part of "customer loyalty" (Watson et al. 2015). Table 1 presents the constructs included in our conceptual model, their definitions, and common synonyms; we discuss them in more detail in the next section.

\section{[Insert Table 1 about here]}

The causal ordering of the variables in our nomological framework (see Figure 1) is based on existing research on relational benefits and theoretical considerations. Palmatier et al.'s (2006) relational mediators meta-analytic framework serves as a starting point for building a conceptual framework of the outcomes of relational benefits. In particular, they specify a relational benefits $\rightarrow$ relationship quality $\rightarrow$ customer loyalty path, and we seek to extend their framework in five ways, by drawing on insights from other empirical studies. First, we distinguish three types of relational benefits (Gwinner et al. 1998), rather than considering relational benefits as a unidimensional construct (Palmatier et al. 2006; Verma et al. 2015). Second, we model perceived value as a mediator of the relational benefits $\rightarrow$ relationship quality relationship (Gummesson 1987; Ravald and Grönroos 1996). Third, we consider switching costs as an additional mediation process underlying the relational benefits $\rightarrow$ customer loyalty relationship (Chang and Chen 2007). Fourth, we specify a path from relationship quality to 
switching costs (Pick and Eisend 2014). Fifth, in line with Watson et al.'s (2015) meta-analysis, we consider firm sales performance as an outcome of customer loyalty.

\section{[Insert Figure 1 about here]}

\section{Relational benefits in services}

Gwinner et al. (1998) seek to understand why customers might want to form and maintain relationships with service firms. The reasons firms would want to form relationships with customers had been well-documented (Morgan and Hunt 1994; Reichheld 1996), but customers' reasons and the benefits that they might derive had not been as well articulated prior to that study. Using a mix of qualitative and quantitative methods, Gwinner et al. (1998, p. 102) define relational benefits that "customers receive from long-term relationships above and beyond the core service performance," and they propose three types (see Table 1).

Confidence benefits ${ }^{3}$ imply reduced anxiety and less perceived risk associated with purchasing the service, because the customer has developed a relationship with the provider and knows what to expect (Gwinner et al. 1998). Confidence benefits are derived from an intimate relationship with the service provider and make a customer feel more secure, escalating the customer's trust level (Chou and Chen 2018). Social benefits run the spectrum from personal recognition by employees to familiarity to friendship — all gained by cultivating a relationship with the firm (Gwinner et al. 1998). Customers often value their social relationships with frontline service providers that result from repeated, interpersonal interactions. Special treatment benefits combine customization (e.g., preferential treatment, extra attention) and economic (e.g.,

\footnotetext{
${ }^{3}$ The terms "confidence" and "trust" are often used interchangeably. However, confidence explicitly refers to "perceived certainty about satisfactory partner cooperation" (Das and Teng 1998, p. 492) and the belief that the partner will behave in a desired manner (Scheer 2012), so it involves expectations about the partner's predictable behavior but does not address the underlying reasons. In contrast, "Trust is the belief that one's partner [a service provider] can be relied upon to fulfill its future obligations and to behave in a manner that will serve the firm's [customer's] needs and long-term interests" (Scheer and Stern 1992, p. 134), because the partner is motivated by more than its own immediate, direct self-interest, a motive that should persist in the future. Thus, trust and confidence are not equivalent; confidence may exist, despite a lack of trust. But trust and confidence also can be related, in that trust can generate general confidence in a business partner (Scheer 2012, p. 338).
} 
price discounts, faster service) elements, such that customers with relationships with the service provider may get better deals, faster service, or more personalized offerings compared with others who lack a relationship with the provider (Gwinner et al. 1998). This special treatment might be structured (e.g., loyalty reward programs) or unstructured (e.g., occasional price break, special services). The concept of relational benefits gave rise to a continuing stream of research that has extensively examined customer responses associated with relational benefits. We develop hypotheses about the consequences of relational benefits next.

\section{Perceived value}

Customer perceived value is generally conceptualized as a customer's overall assessment of the utility of a relationship with a service provider based on perceptions of the benefits received and costs incurred (Zeithaml 1988). Several scholars propose a relationship between relational benefits and perceived value (e.g., Chen and $\mathrm{Hu}$ 2010). This relationship is theoretically rooted in utility theory, which holds that customers derive value according to the difference between the utility provided by buying a certain service (or engaging in a certain activity) and the disutility represented by the price paid or the sacrifices made to attain the service (or engaging in that particular activity) (Sánchez-Fernández and Iniesta-Bonillo 2007). In the context of our study, we contend that customers perceiving higher levels of confidence, social, and special treatment benefits likely perceive higher levels of utility from being loyal to an organization, increasing the difference in the utility/disutility trade-off. Against this backdrop, we expect (Ulaga and Eggert 2006):

H1: (a) Confidence benefits, (b) social benefits, and (c) special treatment benefits are positively associated with perceived value.

\section{Relationship quality}


Relationship quality represents a higher-order construct that reflects the strength of an exchange relationship (Garbarino and Johnson 1999; Hennig-Thurau et al. 2002). Although debate continues about which dimensions constitute relationship quality, prior conceptualizations typically include (relationship) satisfaction, trust, and commitment as indicators (e.g., De Wulf et al. 2001). Palmatier et al. (2006) define relationship quality as an affective state resulting from the overall assessment of a relationship, based on relationship satisfaction, trust, and commitment. Palmatier et al.'s (2006) meta-analysis reveals that the broad concept of relationship quality — rather than its specific dimensions — best captures the strength and breadth of a relationship between customers and service providers.

Drawing on social exchange theory as a theoretical anchor, we contend that relational benefits contribute to higher levels of relationship quality, as perceived by customers. The basic principle guiding social exchange in a relationship marketing context is reciprocity (Bagozzi 1995), in that a person who receives something favorable or valuable from another person wants to restore the balance by being more favorable toward that person and displaying more favorable behavior (Adams 1965). Investing time, effort, and other resources create psychological bonds (De Wulf et al. 2001) and cultivate mutual understanding, trust, satisfaction, and commitment (e.g., Gwinner et al. 1998; Palmatier et al. 2009). Therefore, we expect:

H2: (a) Confidence benefits, (b) social benefits, and (c) special treatment benefits are positively and directly associated with relationship quality.

\section{Perceived value as a mediator between relational benefits and relationship quality}

Value is a core concept in social exchange theory, because each actor evaluates the input and output of another actor, against his or her own input and output, during an interaction (Adams 1965). Emerson's (1976, p. 340) value proposition (i.e., the more valuable the exchange is to a person, the more likely he or she is to perform that action) and rationality proposition (i.e., 
people tend to choose options with higher value and a higher chance of occurring) both suggest that if the outcome and the process of an exchange is valuable, people engage in more exchanges. If being loyal to a service provider brings several benefits to the table that make customers perceive this exchange relationship as more valuable, they prefer to restore the imbalance (i.e., having received several benefits) and reciprocate by developing a stronger relationship with that firm (Crosby et al. 1990). Gummesson (1987) accordingly considers relationship quality a consequence of an accumulation of value over multiple interactions between a customer and a provider. Ravald and Grönroos (1996) similarly propose that relationships develop because of the value that customers extract from a relationship with a service provider. Because perceived value generally is considered an antecedent of relationship quality (Moliner 2009), relational benefits may be positively related to relationship quality through the mediating process of perceived value too. ${ }^{4}$

Whether perceived value fully or only partially mediates the relationship of relational benefits with relationship quality is unclear. Typically conceived of as the result of a rational decision-making process (Zeithaml 1988), perceived value primarily captures the utilitarian outcomes of being in a relationship with a service provider. We argue that relational benefits still have a direct effect on relationship quality (partial mediation of value), which captures the affective outcome of being in a relationship (Palmatier et al. 2006). The utilitarian notion of customer value cannot capture, for example, a close connection between customers and service providers that creates more enjoyable interactions or motivates customers to develop favorable perceptions of that relationship (Price and Arnould 1999). We expect that perceived value

\footnotetext{
${ }^{4}$ In several places herein, we refer to this sequential mediation path (relational benefits $\rightarrow$ perceived value $\rightarrow$ relationship quality $\rightarrow$ customer loyalty). Generally, if either perceived value or relationship quality is present, customers perceive them in a positive light, so these factors keep customers in relationships because they want to (cf. switching costs, often viewed in a negative light, such that they keep customers in the relationship because they have to) interact. We use "PV/RQ path" to refer to this sequential mediation path in the remainder of the text.
} 
partially mediates this relationship, and a direct effect of relational benefits on relationship quality remains even after including perceived value as a mediating mechanism. Formally, H3: Perceived value partially mediates the relationships of (a) confidence benefits, (b) social benefits, and (c) special treatment benefits with relationship quality.

\section{Relationship quality as a mediator between perceived value and customer loyalty}

Perceived value is positively associated with relationship quality (Moliner 2009; Ravald and Grönroos 1996), and several studies support a positive relationship between relationship quality and customer loyalty (e.g., Palmatier et al. 2006). Therefore, we also contend that relationship quality mediates the relationship between perceived value and customer loyalty. Lam et al. (2004) conceptualize value as a cognition-based construct and suggest perceived value influences customer loyalty through a cognition-affect-behavior model. In a similar manner, Ulaga and Eggert (2006) rely on Fishbein and Ajzen's (1975) theory of reasoned action to predict a relationship between customer value and loyalty, such that the effect of the cognitive variable (i.e., perceived value) is mediated by an affective variable (i.e., relationship quality) to result in a behavior (i.e., customer loyalty). Palmatier et al.'s (2006) meta-analysis also offers support for a positive relationship between relationship quality and customer loyalty.

H4: Relationship quality mediates the relationship between perceived value and customer loyalty.

\section{Switching costs}

Customers maintain relationships not only because they want to (PV/RQ perspective) but also because they have to (i.e., switching costs perspective; Geiger et al. 2012). Switching costs refer to the economic and psychological costs that people perceive, anticipate, or experience when changing a relationship from one provider to another (Jones et al. 2002), and they provide insights into why customers might be motivated to remain in relationships. 
Hennig-Thurau et al. (2002) assert that relational benefits increase customer-perceived switching costs. Lam et al. (2004, p. 297) suggest that switching decisions "may involve loyalty benefits that have to be given up by a customer when his or her relationship with the service provider ends." Relational benefits often create switching costs because when people decide to leave a service provider, they also risk losing all benefits they have accrued for being loyal to that particular organization (Chang and Chen 2007). In particular, Lam et al. (2004) predict higher switching costs when customers have developed well-known routines and procedures for dealing with a certain organization, which we consider confidence benefits. When they switch, customers must become familiar with a new organization, which invokes psychological (i.e., increased anxiety) and economic costs. Similarly, customers who enjoy social benefits due to friendly relations with employees often express loyalty toward a particular employee (Bove and Johnson 2006; Palmatier et al. 2007), which makes it harder to switch (Jones et al. 2002). Finally, special treatment benefits imply better deals or lower prices for loyal customers, so if they switch, they would have to give up these benefits (Chang and Chen 2007).

We contend that the three relational benefits have different relationships with switching costs. Confidence benefits and social benefits build up gradually over the course of multiple interactions between customers and service providers, and both are very difficult for competitors to mimic when acquiring a new customer. In contrast, competitors often use price discounts or other promotions to attract new customers (Villanueva et al. 2008), making it easier for customers to attain similar special treatment benefits by switching to a competitor. As a result, we expect that confidence benefits and social benefits are more strongly related to switching costs than special treatment benefits are.

H5: (a) Confidence benefits, (b) social benefits, and (c) special treatment benefits are positively associated with switching costs. 
H6: Confidence benefits and social benefits are more strongly associated with switching costs than special treatment benefits are.

Switching costs also are associated with customer loyalty: Higher switching costs reduce the likelihood that customers leave the organization (Blut et al. 2015; Lam et al. 2004; Pick and Eisend 2014). Customers planning to switch from an organization risk not only incurring direct financial costs (i.e., set-up costs and monetary losses) but also losing knowledge (i.e., learning the service provider's processes), forgoing special benefits (e.g., customized services), and perhaps relinquishing personal relationships (Burnham et al. 2003). Accordingly, customers tend to remain loyal to an organization if they perceive the benefits they accrue from being loyal to that organization would be lost if they were to switch providers. We hypothesize:

H7: Switching costs mediate the relationships of (a) confidence, (b) social, and (c) special treatment benefits with customer loyalty.

Researchers have debated whether the PV/RQ perspective (i.e., perceived value $\rightarrow$ relationship quality $\rightarrow$ customer loyalty) and the switching costs perspective are independent or related processes. Lam et al. (2004) consider switching costs independent of the PV/RQ perspective; Scheer et al. (2010) support a bidimensional model, with separate paths from benefit-based dependence (i.e., relational benefits) versus cost-based dependence (i.e., switching costs) to loyalty. In contrast, Pick and Eisend (2014) propose a path from relationship quality to switching costs—-suggesting that customers lose the benefits from their relationship with a firm when they leave. Giving up valuable and high-quality relationships may be difficult and increase switching costs. Against this backdrop, we hypothesize:

H8: Relationship quality is positively associated with switching costs.

\section{Consequences of customer loyalty}


For completeness, we also specify a relationship between customer loyalty and firm sales performance (e.g., sales, share of wallet, cross-buying behavior). Watson et al. (2015) report a significant effect of a higher-order construct of customer loyalty, which includes both attitudinal and behavioral elements, on performance. We hypothesize:

H9: Customer loyalty is positively associated with firm sales performance.

\section{POTENTIAL MODERATORS}

Our selection of moderator variables was guided by their emergence during our coding process. In particular, we observed that relational benefits have been examined in contexts where the potential for relationship formation is high (e.g., relationship service in which customers tend to interact with the same provider) or low (e.g., encounter service where customers interact with different providers). Moreover, relational benefits have been studied in both business-to-business (B2B) and business-to-consumer (B2C) domains, with potential implications for the relationship marketing outcomes (e.g., Palmatier et al. 2006). During the 20 -year period in which research on relational benefits has emerged, a variety of relationship marketing practices also have emerged (Kumar and Reinartz 2018). Therefore, we examine how the importance of relational benefits for driving customer outcomes has evolved over time, using the differences in the methodological approaches adopted by prior studies as control variables (e.g., single versus multiple industries, student versus non-student samples, publication status).

In the following sections, we develop hypotheses regarding the moderating effects in the relationships of the three relational benefits with the entire set of customer outcomes (i.e., perceived value, relationship quality, switching costs, customer loyalty, and firm sales performance). This multivariate approach to the moderator analysis reflects a common constraint: In many cases, an insufficient number of effect sizes is available to test the moderators at the univariate level, resulting in unstable parameters for the moderator analysis. A 
multivariate approach thus is becoming increasingly common in meta-analyses in marketing (e.g., Pick and Eisend 2016; Van Vaerenbergh et al. 2018).

\section{Type of service: Encounter versus relationship}

The effect of relational benefits may differ depending on whether the service is encounter-based (e.g., fast food) or relationship-based (e.g., hairstylist) (Brown and Lam 2008). In encounter services - sometimes also referred to as transactional services - customers interact with a different service provider every time, in brief, impersonal interactions. The interactions with different employees create greater variability and uncertainty in service performance. In relationship services, customers seek out and mostly interact with the same service provider over an extended period of time, which provides more opportunities for the diffusion of affect and creation of social bonds (Brown and Lam 2008). Customers of relationship services likely know what to expect.

The accessibility-diagnosticity perspective also suggests that information that is more diagnostic and clearly discriminates among alternate categorizations strongly informs judgments and choice (e.g., Herr et al. 1991). The impact of a benefit likely differs in its diagnosticity for future relationship evaluations, depending on whether it is experienced in an encounter or a relationship setting. Specifically, high levels of confidence, social, or special treatment benefits may be more diagnostic (with more value) in an encounter setting, in which they are surprising and exceed customer expectations, versus a relationship setting, in which such benefits are expected. For example, customers of encounter services generally have weaker bonds with the service provider, and social interactions are less frequent (Brown and Lam 2008). Because relational benefits are thus both less frequent and more highly valued, they should be more diagnostic of future evaluations. In line with this accessibility-diagnosticity perspective, we 
hypothesize that confidence, social, and special treatment benefits have stronger relationships with customer outcomes in encounter services than in relationship services. ${ }^{5}$

H10: (a) Confidence benefits, (b) social benefits, and (c) special treatment benefits have a stronger relationship with customer outcomes in encounter services than in relationship services.

\section{Type of market: B2B versus B2C}

Relative to B2C customers, B2B customers tend to exhibit lower levels of customer loyalty, more carefully consider the trade-offs between costs and benefits, and focus more on long-term benefits (Lam et al. 2004; Palmatier et al. 2006; Ulaga and Eggert 2006). These customers also tend to invest more in long-term relationships once the relationship is established (Pick and Eisend 2014). The accessibility-diagnosticity perspective, which suggests that relational benefits are more diagnostic, implies they should be more valuable in a B2B setting, where relational benefits are more exceptional. That is,

H11: (a) Confidence benefits, (b) social benefits, and (c) special treatment benefits have a stronger relationship with customer outcomes in B2B settings than in B2C settings.

\section{Year of publication}

In recent years, marketplaces have changed dramatically. Competition has increased significantly due to globalization, technology allows customers to make better comparisons across competitors, customers have increasing expectations regarding services, and customers are less loyal than ever (Kumar and Reinartz 2018). Customers also place greater emphasis on

\footnotetext{
${ }^{5}$ Over time, firms providing encounter services may learn about the positive effects of relational benefits and move toward a shared industry norm of providing such benefits, tilting the transactional-relational balance more toward a relationship-based setting. Take Starbucks as an example: Buying a cup of coffee once was clearly an encounter service, but Starbucks added relationship elements to its service (e.g., remembering the names and favorite drinks of regular customers). Over time, coffee shops largely adopted these relationship elements, moving the entire industry toward a stronger relationship focus. Still, in the short run and in line with the accessibility-diagnosticity perspective, we predict that confidence, social, and special treatment benefits have stronger relationships with customer outcomes for encounter services than for relationship services.
} 
convenience and the value the organization adds beyond the core service (Kumar and Reinartz 2018). Three particular trends are noteworthy in the context of relational benefits. First, customers face more and more time constraints, meaning they do not always have time to engage in an extensive comparison of alternatives. Time-strapped customers might react more favorably to organizations that provide confidence benefits, which saves them time and effort rather than requiring them to search for other suitable alternatives. Second, marketing activities involve fewer customer-employee interactions (e.g., technology replacing customer-employee interactions), so social benefits may become more important to customers seeking a personal connection. Third, customers are increasingly price sensitive, looking for good deals and ways to save money. These features are key examples of special treatment benefits, which thus may grow more important over time. Many of these evolutions started emerging in the midst of the first decade of the 21 st century, requiring marketers to rethink their approaches to relationship marketing (Kumar and Reinartz 2018). Against this backdrop, we hypothesize:

H12: (a) Confidence benefits, (b) social benefits, and (c) special treatment benefits have stronger relationships with customer outcomes in more recent studies than in earlier studies.

\section{Control variables}

We include three control variables in our analysis. First, as Geyskens et al. (1998, p. 223) note, "multiple industries yield more variation in the data than a single industry ... this should increase the range on the constructs of interest and consequently have a positive effect on the magnitude of the correlation coefficient." Therefore, relational benefits should have a stronger effect for multiple-industry samples. Second, studies of relational benefits differ in their use of a student or non-student sample. Students are atypical respondents in many contexts, due to their limited consumption experiences and different cognitive structures, leading them to weight 
attributes differently than other customers (Peterson and Merunka 2014). Consumer behavior research also reveals that older people tend to form habits more easily, rather than engaging in extensive information processing (Gilly and Zeithaml 1985). Students, who are typically young consumers, thus may evaluate the benefits they receive from an organization more extensively, whereas non-student, typically older consumers could rely more on habitual buying behavior. We then expect relational benefits to be more strongly related to customer outcomes in student samples than in non-student ones. Third, published papers typically report stronger effect sizes than unpublished papers (McAuley et al. 2000). We control for the publication status of a study.

\section{METHOD}

\section{Literature search and criteria for inclusion}

We used several approaches to retrieve published and unpublished articles examining relational benefits. We started with an ancestry approach, in which we examined more than 3000 papers that cite Gwinner et al.'s (1998) work on different types of relational benefits, as well as more than 2600 papers that cite a follow-up study by Hennig-Thurau et al. (2002). All papers citing one of these two articles were examined in detail. In a second step, we conducted a computerized bibliographical search across all relevant databases (ScienceDirect, Ebsco, Social Science Research Network, Web of Knowledge, Emerald) using search terms such as "relational benefits," "relationship benefits," “confidence benefits," "social benefits," "special treatment benefits," "functional benefits," "trust benefits," and "psychological benefits." In a third step, we repeated this computerized bibliographical search using Google Scholar and Google as search engines, which might help us identify unpublished studies. Fourth, we performed a manual search of marketing or marketing-related journals publishing papers on relational benefits (see Web Appendix A for a list of the manually searched journals). Fifth, we undertook these four steps again, using keywords similar to relational benefits, such as "relational bonds," "social 
bonds," "economic bonds," "relationship marketing investments," "relationship marketing efforts," and "relationship marketing strategies," 6 to find additional pertinent articles that might not contain the precise term "relational benefits."

As defined in Table 1, relational benefits were conceptualized and measured as the confidence, social, and/or special treatment benefits that customers receive from being loyal to a service provider. In choosing studies for this meta-analysis, we applied four inclusion criteria. First, studies must have examined at least one of the three distinct relational benefits, as defined in Table 1, instead of conceptualizing and/or operationalizing relational benefits as a single, general construct. Second, studies must have examined at least one of the following constructs: perceived value, relationship quality, switching costs, customer loyalty, or firm sales performance. Third, the studies needed to be quantitative in nature and contain sufficient statistical information to extract effect sizes. Most studies report correlations, and the correlation coefficients serve as effect size metrics. We either extracted the correlations directly, using the zero-order correlation reported, or indirectly, by converting other statistical data (e.g., standardized beta coefficients, $t$-values) into a correlation coefficient using the relevant formula (Hunter and Schmidt 2004; Peterson and Brown 2005). Fourth, because we consider Gwinner et al.'s (1998) article as a starting point for research on different types of relational benefits, we include studies published from 1998 onward.

This procedure resulted in a set of 224 papers, some of which included more than one independent sample. Multiple papers presenting results from the same sample were treated as a single study. We coded the paper published earliest first, after which we coded any additional information from subsequent papers using the same set of data. Conversely, multiple independent samples presented in a single paper (e.g., multi-study papers with independent data

\footnotetext{
${ }^{6}$ We are grateful to one of the reviewers for the suggestion to include these additional keywords.
} 
sets) were treated as separate studies. Overall, this meta-analysis thus covers 235 independent samples, with a combined total of 97,803 respondents. Web Appendix B lists the papers included in this meta-analysis; Web Appendix C offers some descriptive statistics about these studies.

\section{Coding of studies}

In a method similar to that described by Zablah et al. (2012), one experienced metaanalyst read each article and coded all available correlations (or other statistics) for relationships between any constructs in our conceptual framework, sample sizes, and construct reliabilities. Intercoder agreement about information from primary studies is a concern in meta-analysis but typically is not a problem for coding statistical information (Geyskens et al. 2006). Judgment calls during the coding process were discussed with the other authors as needed; two issues required particular attention. First, as we systematically reviewed the studies, measures of relational benefits, and the five outcome variables, we encountered highly similar measurement scales that were labeled differently. Therefore, we referred to the original scales and items in each study; studies sometimes use the same label for different relational benefits and/or outcome variables (see Table 1). We classified the different variables according to the construct definitions in Table 1, to avoid a situation in which we combined dissimilar constructs or separated conceptually equivalent or similar constructs. Second, if studies reported two or more correlations for the same relationships (e.g., associations of confidence benefits with trust and commitment, both of which indicate relationship quality), we combined them into a composite correlation, using Hunter and Schmidt's (2004) formulae.

Our final sample includes 1242 correlations. Thirty percent of the studies include only one of the three relational benefits in their research models, $33 \%$ include two relational benefits, and the remaining $37 \%$ examine all three relational benefits simultaneously. A detailed breakdown of the combination of relation benefits studied can be found in Web Appendix D. 
In a next step, two independent reviewers coded the moderators using a predefined coding scheme (see Web Appendix E), with an agreement rate of 98\%. Disagreements were resolved through discussion. In particular, the coders were instructed to determine whether the study was conducted in a B2B or B2C market (i.e., the buyer is another firm or a consumer, respectively), whether the data were collected in a single industry (e.g., restaurants) or in multiple industries (e.g., restaurants, hotels, airlines, and banks in one study), and whether the data collection involved a student or non-student sample. In line with Brown and Lam (2008), coders also had to determine whether the service being studied can be defined as a relationship business (i.e., service in which customers typically seek out the same employee over the course of multiple interactions) or an encounter business (i.e., service in which customers typically encounter different employees over the course of multiple interactions). In addition, we coded the year in which the study was published. Approaches to relationship marketing changed notably around the midpoint of the time of our sample (i.e., 2005/2006), due to the various changes in technology (e.g., introduction of Facebook and Twitter), consumer behavior, and markets, as we noted previously. Therefore, we created a dummy variable to capture this evolution. Imposing the time lag required for academic publication, we used 2009 as a cut-off date. $^{7}$

Of the 224 papers, about $84 \%$ were published in academic journals; the remaining $16 \%$ include unpublished doctoral dissertations, master's theses, working papers, or conference proceedings. The study participants are students in $7 \%$ of the studies, and slightly less than $82 \%$

\footnotetext{
${ }^{7}$ We are grateful to the Associate Editor and a reviewer for their suggestion to include a dummy variable to represent changes in the relationship marketing environment. To define a reasonable time lag between the year of data collection and the year of publication, we calculated the differences between the date a paper was received and the date it was published in the May 2019 volume of Journal of the Academy of Marketing Science (average: 1.7 years), then added an extra year to account for the manuscript writing process. Therefore, we anticipate an average time lag of about three years, such that a paper published in 2009 likely reflects data collected in 2006. Our results remain stable if we use two- or four-year time lags instead.
} 
of the studies focus on a B2C setting. Eighty-six percent of studies examine relational benefits in a single industry. Studies focusing on encounter services in which customers interact with a different service provider each time account for $49 \%$ of our sample, while $37 \%$ refer to relationship services in which customers interact with the same employee for each service provision (Gutek et al. 1999). The remaining 14\% of studies examine relational benefits in multiindustry settings. Web Appendix F provides an overview of the study characteristics.

\section{Effect size integration}

With a random-effects model, we integrate the correlations as a mean effect size. Following standard meta-analytic practices, we first correct the correlation coefficients for measurement error by dividing them by the product of the square root of the reliabilities for both constructs. If this information is missing, the sample size-weighted mean reliability provides an approximation (Van Vaerenbergh et al. 2018). In a next step, we correct for sampling error by weighting the reliability-corrected correlation coefficients by sample size (Hunter and Schmidt 2004). In line with Field's (2001) recommendation, we did not apply a Fisher z-transformation when integrating effect sizes, because these correlations would underestimate the coefficients' actual variance and overestimate the effect size of heterogeneous correlations (as are typical in marketing studies) by $15 \%$ to $45 \%$.

\section{Path model estimation}

To test the nomological model in Figure 1, we use structural path analysis. This analysis requires a meta-analytically derived correlation matrix as input. In total, our conceptual framework contains eight variables, which means that 28 off-diagonal cells of a correlation matrix need to be filled. We calculated meta-analytic correlations among all constructs in our conceptual framework and used these correlations to create a meta-analytic correlation matrix. All constructs were observed variables. The relationships between the various constructs were 
specified as shown in Figure 1. In addition, we allowed for correlations among the three relational benefits. We used the harmonic mean of the cumulative sample sizes across all relationships as the sample size for the analysis $(n=11,633)$. The harmonic mean assigns less weight to larger samples, so it offers a more conservative test than the arithmetic mean. Similar to Hong et al. (2013), we evaluate model fit using the chi square $\left(\chi^{2}\right)$, comparative fit index (CFI), Tucker-Lewis index (TLI), and standardized root mean square residual (SRMR).

\section{Moderator analysis}

We employed multivariate, multilevel meta-regressions to test for the effect of the moderators for two main reasons. First, meta-regressions often suffer from a lack of statistical power, due to the limited number of observations per individual relationship (Hox 2010), and we did not propose hypotheses specific to univariate relationships. Therefore, we test the moderating effects at the multivariate level. Second, the samples in our meta-analysis typically provide more than one effect size estimate. Multiple effect sizes provided by one sample cannot be considered independent (Hox 2010), and ignoring these dependencies can lead to an underestimation of standard errors. Multilevel meta-regressions account for these dependencies.

The multilevel model for this meta-analysis consists of two levels: the first incorporates information about the correlations, and the second provides information about the studies that provide these correlations. Basically, Level 1 includes information about relationships that vary within studies, whereas Level 2 includes information about study characteristics that vary between studies. We ran three models — one for each type of relational benefit.

We specified the model using Hox's (2010) guidelines, such that we regressed the reliability-corrected correlations on five dummy variables at Level 1 , representing each dependent variable that correlated with relational benefits, as well as six moderators at Level 2. The moderators include the type of service (encounter versus relationship), type of market (B2C 
versus B2B), publication year (published before 2009 versus during/after 2009), sample (nonstudents versus students), the number of industries sampled (single versus multiple), and publication status (published versus unpublished). Thus, the model is as follows:

(1) Level 1

$$
\begin{aligned}
E S_{i j}= & \beta_{0 j}+\beta_{1 j} \times\left(\text { Perceived value }_{i j}\right)+\beta_{2 j} \times\left(\text { Switching cost }_{i j}\right)+\beta_{3 j} \times \\
& \left(\text { Relationship quality }_{i j}\right)+\beta_{4 j} \times\left(\text { Customer loyalty }_{i j}\right)+\beta_{5 j} \times \\
& \left(\text { Firm sales performance }_{i j}\right)+e_{i j}
\end{aligned}
$$

(2) Level 2

$$
\begin{aligned}
\beta_{0 j}= & \gamma_{01} \times\left(\text { Type of service: Relationship versus encounter } r_{j}\right)+\gamma_{02} \times \\
& \left(\text { B2C versus B2B setting }{ }_{j}\right)+\gamma_{03} \times\left(\text { Publication year }_{j}\right)+\gamma_{04} \times \\
& \left(\text { Single versus multiple industries } \text { in }_{j}\right)+\gamma_{05} \times(\text { Non }- \\
& \text { student versus student samples } \left.s_{j}\right)+\gamma_{06} \times \\
& \left(\text { Published versus unpublished study } y_{j}\right)+u_{0 j},
\end{aligned}
$$

where $E S_{\mathrm{ij}}$ is the $\mathrm{i}^{\text {th }}$ reliability-corrected correlation coefficient reported in the $\mathrm{j}^{\text {th }}$ sample.

Equation 1 details the effect of different correlates of relational benefits that vary within studies. Equation 2 describes the impact of study-level variables on the intercept of the first-level equation, where $e_{\mathrm{ij}}$ refers to the effect size-level residual variance, and $u_{0 \mathrm{j}}$ indicates study-level residual variance. Because we include a dummy variable for each correlate of relational benefits at the effect size level, we omit the intercept (Van Vaerenbergh et al. 2018). The dummy variables at the effect size level thus serve as outcome variable-specific intercepts. To estimate the multilevel model, we use an iterative generalized least squares procedure, which yields maximum likelihood estimates, and estimate it three times, once for each relational benefit we 
investigate. For our directional hypotheses regarding the moderating effects, we use one-sided hypotheses tests.

\section{RESULTS}

\section{Analysis of pairwise relations}

Table 2 lists the reliability-corrected, sample size-weighted correlations among the eight variables in the conceptual framework (see Web Appendix G for full meta-analytic statistics). An inspection of the pairwise correlations among the three relational benefits reveals that they range from .51 to .55 , suggesting the usefulness of treating these variables as separate constructs in our analysis. ${ }^{8}$ The three relational benefits correlate significantly with perceived value, switching costs, relationship quality, customer loyalty, and firm sales performance.

[Insert Table 2 about here]

\section{Path model results}

The correlation matrix in Table 2 provides the input for the path model estimation. The hypothesized model fits the data well $\left(\chi^{2}(11)=1850.99, p<.001 ; \mathrm{CFI}=.96, \mathrm{TLI}=.90, \mathrm{SRMR}=\right.$ $.05)$. The model in Figure 2 accounts for $46 \%$ of the variance in perceived value, $19 \%$ of the variance in switching costs, $65 \%$ of the variance in relationship quality, $52 \%$ of the variance in customer loyalty, and $36 \%$ of the variance in firm sales performance. Figure 2 includes the direct effects of our path model. We also compute indirect effects to assess the mediating effects of perceived value, relationship quality, and switching costs in the relationship between relational benefits and customer loyalty (see Table 3 ).

\footnotetext{
${ }^{8} \mathrm{We}$ also coded the means and standard deviations of the three relational benefits reported in the 235 samples and recalibrated them to $0-100$ scales. The average levels are $67(\mathrm{SD}=16)$ for confidence benefits, $51(\mathrm{SD}=19)$ for social benefits, and $49(\mathrm{SD}=18)$ for special treatment benefits. The $t$-tests reveal that these average levels do not differ significantly between B2B and B2C contexts (all $p>.10$ ). The average level of confidence benefits also does not differ between encounter and relationship services $(p>.10)$, whereas that of social benefits is significantly higher in relationship services (56) than in encounter services $(48 ; \mathrm{t}(77)=2.404, p<.05)$. The average level of special treatment benefits is marginally significantly higher in relationship services (55) than in encounter services $(47 ; \mathrm{t}(77)=1.929, p<.06)$. Web Appendix H provides further detail.
} 


\section{[Insert Figure 2 and Table 3 about here]}

Confidence benefits $(.42, p<.001)$, social benefits $(.31, p<.001)$, and special treatment benefits $(.06, p<.001)$ are significantly related to perceived value, in support of H1a-c. Perceived value, in turn, is positively associated with relationship quality $(.52, p<.001)$. The analysis of the indirect effects (Table 3) reveals that perceived value mediates the relationships of all three relational benefits with relationship quality (confidence: .22, $p<.001$; social: .16, $p<$ .001 ; special treatment: .03, $p<.001)$. Confidence benefits $(.24, p<.001)$, social benefits $(.11, p$ $<.001)$, and special treatment benefits $(.07, p<.001)$ are still directly and positively associated with relationship quality too. Therefore, perceived value partially mediates the relationships of relational benefits with relationship quality, in support of $\mathrm{H} 2 \mathrm{a}-\mathrm{c}$ and $\mathrm{H} 3 \mathrm{a}-\mathrm{c}$. Finally, relationship quality is directly and positively associated with customer loyalty $(.66, p<.001)$. The analysis of the indirect effects (Table 3) reveals that relationship quality mediates the perceived valuecustomer loyalty relationship $(.34, p<.001)$. These findings support H4. Overall, the results support a serial mediation model of confidence benefits $(.14, p<.001)$, social benefits $(.11, p<$ $.001)$, and special treatment benefits $(.02, p<.001)$ on customer loyalty through both perceived value and relationship quality (see Table 3).

Confidence benefits (.13, $p<.001)$, social benefits $(.11, p<.001)$, and special treatment benefits $(.07, p<.001)$ are significantly and positively related to switching costs, in support of H5a-c. To test H6 (i.e., confidence and social benefits have a stronger relationship with switching costs than special treatment benefits), we impose equality constraints. Model fit deteriorates significantly when constraining the confidence benefits $\rightarrow$ switching costs path and the special treatment benefits $\rightarrow$ switching costs path to equality $\left(\Delta \chi^{2}(1)=13.18, p<.001\right)$. The same effect occurs when constraining the social benefits $\rightarrow$ switching costs path and the special 
treatment benefits $\rightarrow$ switching costs path to equality $\left(\Delta \chi^{2}(1)=4.35, p<.05\right)$. These findings support H6.

Switching costs are significantly related to customer loyalty $(.13, p<.001)$. The analysis of the indirect effects (Table 3) reveals that switching costs mediate the relationship between confidence benefits and customer loyalty $(.02, p<.001)$, the relationship between social benefits and customer loyalty $(.01, p<.001)$, and the relationship between special treatment benefits and customer loyalty $(.01, p<.001)$. These findings support H7a-c. ${ }^{9}$ In support of H8, we also find a significant relationship between relationship quality and switching costs $(.21, p<.001)$. As expected, customer loyalty is positively associated with firm sales performance $(.60, p<.001)$ and thus supports H9.

\section{Moderator analysis}

Table 4 contains the results of the moderator analysis on all customer outcomes, which (as described earlier) include perceived value, switching costs, relationship quality, customer loyalty, and firm sales performance. The effects of both confidence $(\gamma=-.03, p>.10)$ and social $(\gamma=-.04, p>.10)$ benefits on all customer outcomes do not differ across relationship or encounter services. In line with our expectations, the relationship between special treatment benefits and customer outcomes is weaker for relationship services than encounter services $(\gamma=$ $.08, p<.05)$; these findings conflict with H10a and H10b but provide support for H10c. Confidence benefits $(\gamma=.11, p<.10)$ and special treatment benefits $(\gamma=.08, p<.10)$ are more strongly associated with customer outcomes in B2B settings than in B2C settings, though the difference is only marginally significant. The moderating effect of B2B versus B2C on the

\footnotetext{
${ }^{9}$ Although not hypothesized, the results reveal that the indirect effect from relational benefits to customer loyalty through perceived value and relationship quality (confidence: .14, $p<.001$; social: .11, $p<.001$; special treatment: $.02, p<.001)$ is stronger than the indirect effect from relational benefits to customer loyalty through switching costs (confidence: .02, $p<.001$; social: .01, $p<.001$; special treatment: .01, $p<.001$ ). Imposing equality constraints on these indirect paths significantly worsens model fit $\left(\Delta \chi^{2}(3)=2590.71, p<.001\right)$.
} 
relationships between social benefits and customer outcomes is not significant $(\gamma=.05, p>.10)$. Thus we find partial support for $\mathrm{H} 11 \mathrm{a}$ and $\mathrm{H} 11 \mathrm{c}$ but not $\mathrm{H} 11 \mathrm{~b}$. The strength of relationships of confidence benefits $(-.03, p>.10)$ and social benefits $(.04, p>.10)$ with customer outcomes do not differ between papers released before 2009 or after 2009. However, special treatment benefits are more strongly associated with customer outcomes in papers published in or after 2009 than in those released before $2009(.10, p<.01)$. These findings support H12c but not H12a and $\mathrm{H} 12 \mathrm{~b}$.

\section{[Insert Table 4 about here]}

We observe a significant difference in the strength of relationships between confidence benefits and customer outcomes for studies that use student versus non-student samples $(\gamma=.15$, $p<.05$ ), as well as marginally significant differences across these samples in the strength of the relationships of social benefits $(\gamma=.12, p<.10)$ and special treatment benefits $(\gamma=.12, p<.10)$ with customer outcomes. Confidence benefits are more strongly related to customer outcomes for studies conducted in multiple, as opposed to single, industries $(\gamma=.15, p<.01)$; this relationship is marginally significant for special treatment benefits $(\gamma=.08, p<.10)$. Finally, special treatment benefits are more strongly associated with customer outcomes in unpublished studies than in published studies $(\gamma=.10, p<.05)$. No other effects are significant.

\section{DISCUSSION}

\section{Theoretical implications}

We make three primary contributions with this meta-analytic study. First, we examine the extent to which each of three individual relational benefits components predicts customer responses, thereby determining which ones have the strongest impact. Our findings extend research on relational benefits that frequently studies outcomes using a single, one-dimensional relational benefit construct (e.g., Palmatier et al. 2006; Verma et al. 2016). Second, we generate 
new knowledge about the processes (combined PV/RQ mediation path and/or switching costs mediation path) through which relational benefits affect customer loyalty. Illuminating these processes represents a contribution to relationship quality/value literature (e.g., Garbarino and Johnson 1999; Martin-Ruiz et al. 2008; Palmatier et al. 2006) and switching cost literature (e.g., Chang and Chen 2007; Hennig-Thurau et al. 2002; Lam et al. 2004); we specify these constructs as the mechanism through which relational benefits lead to customer loyalty. Third, we study which contingency factors (i.e., type of service, type of market, and timing of study) influence these relationships. By identifying these factors, this study helps provide guidelines for appropriate contexts in which to consider managerial implications. We elaborate on these contributions in the rest of this section.

With regard to the first contribution, our results provide empirical generalizations of how each of the three relational benefits components affects customer responses. Both confidence and social benefits exert significant impacts on loyalty, through customer perceived value, relationship quality, and switching costs — each of which serves as a mediator in the relationships. Special treatment benefits consistently have a much weaker, though significant, effect on perceived value, relationship quality, switching costs, and thus on customer loyalty. Among the 224 papers included in this meta-analysis, we consistently find that special treatment is a weak contributor to the process of creating customer loyalty. The resulting insights are important from a theoretical standpoint, because they offer guidance about which relational benefits are most appropriate to include in relationship marketing models and frameworks: Scholars may want to emphasize confidence and social benefits and consider limiting the inclusion of special treatment benefits in their research. These results also suggest that a unidimensional approach to relational benefits (e.g., Palmatier et al. 2006; Verma et al. 2016) might not adequately capture the influence of each benefit component on customer loyalty. 
As our second contribution, we offer insights into the processes through which relational benefits affect customer loyalty. Although prior literature has predicted that relational benefits operate on customer loyalty through a perceived value path (Martin-Ruiz et al. 2008), a relationship quality path (Hennig-Thurau et al. 2002), or a switching costs path (Chang and Chen 2007; Geiger et al. 2012), no simultaneous test of these pathways exists, leaving the importance of each path and their interplay in question. In this study, we (1) model perceived value as a mediator of the relational benefits $\rightarrow$ relationship quality relationship, (2) consider switching costs as an additional process underlying the relational benefits $\rightarrow$ customer loyalty relationship, and (3) propose and then test a relationship between both mediating processes by specifying a path from relationship quality to switching costs.

Our examination of all of these mediation paths - the first meta-analysis to do so simultaneously—suggests that relational benefits influence customer loyalty through all three paths. Furthermore, as we noted in Footnote 9, the path to loyalty from relational benefits is stronger through the PV/RQ path. As such, we can conclude that a positive perspective (i.e., focus on why customers want to stay, based on value, trust, commitment, and satisfaction) rather than a negative perspective (i.e., focus on customers' perceptions that they have to stay in a relationship) provides greater insights into customer loyalty. With respect to the PV/RQ path, all three relational benefits strengthen customer perceived value and thus relationship quality, which in turn increases customer loyalty. In addition to the direct effect of relational benefits on relationship quality, perceived value partially mediates this relationship. Kumar and Reinartz (2016) observe that marketing literature often omits customer perceived value from conceptual models, despite its importance for practitioners; our findings provide empirical justification for including perceived value, in that it better reveals the manner in which relationship quality is influenced by the three relational benefit constructs. 
According to the evidence we obtain of a switching costs path, driven by all three relational benefits, we also note that the presence of relational benefits makes it more difficult for customers to switch providers. These findings provide new insight into Gremler and Gwinner's (2015) question about whether relational benefits are equivalent to switching costs. Our findings suggest that they are distinct constructs—both conceptually and empirically—and that switching costs are what customers perceive when they must relinquish relational benefits received. Thus, relational benefits may engender switching costs, but it appears that switching costs also entail other perceptions of the quality of the customer-firm relationship, beyond its relational benefits.

Then our findings extend relationship marketing theory by providing insights into the independence and interdependence of the mediation processes. Some studies assert that the PV/RQ and switching costs processes are independent (Lam et al. 2004); others specify a path from relationship quality to switching costs (Pick and Eisend 2014). Our findings suggest that even though both paths have direct effects on customer loyalty, the PV/RQ path also reinforces the switching costs path. Therefore, continued efforts to understand relationship marketing outcomes would benefit from modeling both processes simultaneously.

The third contribution comes from our examination of the relationships of relational benefits with customer outcomes in the presence of various contingency factors (i.e., type of service, type of market, and timing of study). Relational benefits are slightly more important in $\mathrm{B} 2 \mathrm{~B}$ than in $\mathrm{B} 2 \mathrm{C}$ service contexts, in line with prior findings that $\mathrm{B} 2 \mathrm{~B}$ customers tend to exhibit lower customer loyalty, consider cost-benefit trade-offs more carefully, and focus more on longterm relationships (Lam et al. 2004; Palmatier et al. 2006; Ulaga and Eggert 2006). Across relationship and encounter services, we do not find any differences in the effects of confidence or social benefits on customer outcomes. However, in line with our expectations, the relationship between special treatment benefits and customer outcomes is not as strong in relationship 
services as it is in encounter services. Although we took an accessibility-diagnosticity perspective (Herr et al. 1991) to argue that relational benefits might be more important in encounter contexts, where they would be surprising and exceed customer expectations, we find that only special treatment benefits appear to exert this differential impact. It thus seems that confidence and social benefits are equally important across encounter and relationship services, but special treatments benefits provide a differential advantage for encounter services.

Our findings also indicate that the effect of relational benefits has changed over time. Specifically, relationships between special treatment benefits and customer outcomes appear stronger in more recent studies - suggesting perhaps that specific environmental trends (e.g., increasing self-service technology, social media influences) exhibit more powerful impacts on later studies than they did previously. The relationships of confidence and social benefits with customer outcomes remain equivalently strong over time though. In terms of methodological moderators, our findings suggest that the use of student samples (a relatively small percentage of studies in our data set) may lead to an overestimation of the effects of confidence and special treatment benefits. Researchers should be cautious when generalizing findings obtained from such samples.

In summary, the moderator variables we examine suggest some boundary conditions for our conceptual model, highlighting where and in which conditions the model applies most effectively: The special treatment benefits-customer outcomes relationship is stronger in encounter services; confidence and special treatment benefits have marginally stronger impacts in B2B settings over B2C settings; and special treatment benefits' relationship with customer outcome variables is stronger in more recent papers (proxy for technology advances).

\section{Managerial implications}


When designing strategies to improve relational benefits, managers might focus more on establishing (or strengthening) confidence benefits and social benefits, both which have much stronger effects on perceived value, relationship quality, and switching costs—and therefore customer loyalty — than do special treatment benefits. To provide confidence benefits, firms must establish consistent, seamless, high-quality customer experiences (Lemon and Verhoef 2016), so that customers know what to expect and have confidence when interacting with the firm. Managers should clearly describe customers' roles in the service process and invest in developing customer skills to make the most of a service, as well as provide frontline employees with clear service scripts that specify the service delivery, while also training them to provide consistent delivery that instills confidence in customers. Offering service guarantees can help reduce purchase risks and increase confidence benefits (Hogreve and Gremler 2009). Managing expectations so that they can be delivered on is also critical. Some firms have found value in providing realistic service previews for their customers to clarify role expectations (Bitner et al. 1997). Advertising that accurately depicts an expected level of service, as long as it then gets delivered consistently, can also reinforce confidence benefits.

Social benefits are important for service firms that want to increase customer loyalty. Frontline employees need to be able to engage socially with customers, and the firm culture must encourage and reward their investments in such activities. To this end, setting measurable goals for interactions, rewarding progress, making social engagement with customers a part of job descriptions, and providing employee training on how to exert the most impact in such interactions is critical. Companies can facilitate the development of social benefits by structuring service delivery processes to encourage interactions of sufficient duration; longer interactions may provide more opportunities for social benefits to develop. However, encouraging longer interactions demands a strategic decision process for firms if industry norms instead embrace 
quick and efficient interactions to maximize the returns on employees' time. A more timeconsuming but personal approach can enable firms to set themselves apart in a crowded industry with many alternative service providers. To overcome the negative aspects of longer interactions, the use of technology may help some firms leverage their delivery of social benefits, from one to many. For example, a clothing retail firm might encourage employees to use company-branded Snapchat accounts to inform customers of new offerings, allowing each employee to interact with many customers online by establishing dialogues about their customer needs. Such an innovation would allow a single employee to reach multiple customers efficiently to cultivate social benefits.

As indicated previously, special treatment benefits appear less effective than the other relational benefits. It is difficult to draw definitive conclusions about the underlying reason, but a possible explanation is that special treatment benefits are relatively prevalent today, compared with confidence and social benefits. When customers contemplate switching service providers, they might assume that any special treatment benefits they have forfeited by leaving will be replaced by the new firm. Popular reward programs (e.g., airlines, hotels) reinforce this notion of special treatment being tied to patronage. For example, the auto insurer Allstate offers "accident forgiveness" to clients after a specified (relatively short) period of time with no further accidents; the insured qualifies for the benefit of not incurring a price increase for auto insurance, even in the event of a future accident, which represents a form of special treatment. In the past, this benefit would have been provided only to long-term customers. As an alternative explanation, we posit that the commonly used promotional incentives directed at new customers may be perceived as more valuable than any special treatment benefits, which might not appear all that "special" to customers. Managers might either place less emphasis on special treatment benefits or else develop special treatment options that are hard to replicate and valued by consumers. 
In a sense, the low importance of special treatment benefits might represent good news for companies; these benefits can be expensive to provide, and firms that choose not to provide them may enjoy direct impacts on their bottom-line financial results. Because these benefits generally can be copied easily by competitors, they are less likely to lead to a sustainable competitive advantage. Customers driven by special treatment benefits may remain loyal only until a competitor offers better benefits; our findings suggest that a diminished emphasis on special treatment benefits can be a prudent strategy. One caveat though is that when the customer views a special treatment benefit as essential (i.e., benefit-based dependence, Scheer et al. 2010), failing to offer it might exclude the firm from the customer's consideration set. Such a scenario may arise if most competitors have enhanced their offering with this benefit, such that what was once viewed as a (differentiating) special treatment factor is now simply a point of parity and an industry standard.

Both processes for realizing the impact of relational benefits (PV/RQ path and switching costs path) drive the effect of relational benefits on customer outcomes. This finding is good news for managers, whose investments in relational benefits can pay off in two ways. On the one hand, all three relational benefits increase perceived value, which improves relationship quality and customer loyalty. On the other hand, confidence and social benefits increase customers' relationship dependency and raise the costs of switching to another organization. Those switching costs then increase customer loyalty. In terms of prioritizing one path over another, our analysis indicates that the PV/RQ path has a greater influence on customer loyalty. Even if both paths are beneficial, promotional messages emphasizing value and relational quality elements, driven by the presence of relational benefits, may be more effective.

\section{Limitations and further research}


The current research suffers the limitations inherent to any meta-analysis. First, the availability of information is limited, because some articles do not report sufficient statistical information to be included. For example, we identify seven distinct relational benefits in prior literature but had to exclude four that do not appear in a sufficient number of studies. More research on other relational benefits-including, but not limited to, identity-related, respect, hedonic, and quality improvement benefits-is necessary to understand their relative effectiveness for fostering customer loyalty. The notion of "relational costs," which could be conceived of, in line with relational benefits, as the costs that accrue when a customer is loyal, is an interesting one, virtually absent from prior literature. To understand the relationship between a customer and an organization, these costs should be accounted for and included in new studies. In addition, even though Palmatier et al. (2007) demonstrate differential effects of loyalty toward an organization and loyalty toward a frontline employee, this meta-analysis includes only customer loyalty toward an organization as an insufficient number of studies examine customer loyalty toward a frontline employee. However, such examination might be theoretically relevant to undertake. For example, switching costs may be less likely to drive customer loyalty when a customer's loyalty is focused toward an employee rather than an organization.

Second, differences in the strengths of the effects of the relational benefit variables could be attributed to measurement issues. Methodological problems can affect the results of any individual study, though they are unlikely to have had a significant impact on our empirical generalizations, which are based on 1242 correlations from 235 independent samples reported in 224 papers. The majority of papers in our meta-analysis have been published in peer-reviewed journals, which assures a certain level of quality. However, methodological concerns cannot be ruled out completely and should receive more attention in further research. Related to this point, researchers examining relational benefits rely almost exclusively on survey-based methods. 
More studies using experimental designs are necessary to make causal inferences about the consequences of relational benefits.

Third, we call for more research on the moderators of the relationships we examine, especially studies that seek to identify conditions that moderate the mediation effects we assessed. In a meta-analysis, examining such conditions is not possible, because we rely on the summary statistics reported in each article rather than the original data. Our moderator analysis relies on a multivariate approach, which enhances its statistical power. As more data become available, particularly for the perceived value and switching costs constructs, continued research could examine whether the two mediation paths (PV/RQ and switching costs) operate differently across contingent factors. For example, the switching cost mechanism might exert a stronger influence in $\mathrm{B} 2 \mathrm{~B}$ than in $\mathrm{B} 2 \mathrm{C}$ contexts. Also, there are other ways to classify types of service besides the "encounter-based vs. relationship-based" classification (Brown and Lam 2008) that we use. Future research might benefit from considering other service classifications and perhaps reveal additional moderating effects. And, we use publication year as a proxy for the year of data collection, which typically is not reported. Researchers might use longitudinal approaches to study how the effect of relational benefits on customer outcomes has evolved over time.

Fourth, relatively few studies examine antecedents of customer relational benefits, so we could not include them in the current study. More research examining how relational benefits develop is necessary. Even though relational benefits originally were conceptualized as a consequence of customer loyalty (Gwinner et al. 1998), virtually all studies examine customer loyalty as a consequence of relational benefits. Research with a longitudinal approach could examine these reciprocal relationships over time and might provide insights into which relational benefits contribute most to customer loyalty across the stages of a customer lifecycle. For example, perhaps confidence benefits are particularly important in the early stages of a 
relationship, whereas social benefits need to more time to develop. The type of service (encounter versus relationship, B2B versus B2C) also might drive the nature of the benefits. A related extension might examine the interactions of the various relational benefits. In this study, we consider relational benefits independent; testing their interactions would offer an interesting contribution. On this point, our meta-analysis is limited in that we must rely on statistics reported by other authors in their papers. Virtually all these studies examine only the main effects of relational benefits, so we cannot include interaction effects. We encourage scholars to test for potential interactions across the various relational benefits.

Fifth, factors such as products versus services or contractual versus non-contractual settings also could affect the results. Studies examining relational benefits are rooted in service research; further research should test relational benefits in product industries. Moreover, other mediating mechanisms may be at work, such as gratitude and entitlement (Wetzel et al. 2014). Our meta-analysis draws inferences from existing studies on relational benefits that have not addressed these context factors fully. We therefore encourage more research in these areas. Given our findings related to perceived value and switching costs, it may also be interesting for future research to examine the effects of relational benefits on both relationship value dependence and switching cost dependence (cf. Scheer et al. 2015). Dependence is seldom explicitly measured in services studies (see Scheer et al. 2015 for an exception), but there may be contributions to be made in more cross-pollination between service research and research on interdependence/dependence in marketing relationships.

Sixth, the use of technology to facilitate service delivery is an understudied consideration for relational benefits. With the help of artificial intelligence, technology delivers increasingly consistent service (perhaps fueling confidence benefits) and provides customized solutions (special treatment benefits) that seem personal to customers (social benefits). Services that once 
were possible only in face-to-face settings, such as personalized tourism recommendations (Ardissono et al. 2003) or medical diagnoses and treatment (Dilsizian and Siegel 2014), now are performed primarily with the help of artificial intelligence. A logical next step is for scholars to examine how to facilitate customer-technology interfaces that engender relational benefits. 


\section{REFERENCES}

Adams, J. S. (1965). Inequity in social exchange. In L. Berkowitz (Ed.), Advances in Experimental Social Psychology, (pp. 167-299). New York: Academic.

Ardissono, L., Goy, A., Petrone, G., Segnan, M., \& Torasso, P. (2003). Intrigue: Personalized recommendation of tourist attractions for desktop and hand held devices. Applied Artificial Intelligence, 17(8-9), 687-714.

Bagozzi, R. P. (1995). Reflections on relationship marketing in consumer markets. Journal of the Academy of Marketing Science, 23(4), 272-277.

Bitner, M. J., Faranda, W. T., Hubbert, A. R., \& Zeithaml, V. A. (1997). Customer contributions and roles in service delivery. International Journal of Service Industry Management, 8(3), 193-205.

Blut, M., Frennea, C. M., Mittal, V., \& Mothersbaugh, D. L. (2015). How procedural, financial, and relational switching costs affect customer satisfaction, repurchase intentions, and repurchase behavior: A meta-analysis. International Journal of Research in Marketing, $32(2), 226-229$.

Bove, L. L., \& Johnson, L. W. (2006). Customer loyalty to one service worker: Should it be discouraged? International Journal of Research in Marketing, 23(1), 79-91.

Brown, S. P., \& Lam, S. K. (2008). A meta-analysis of relationships linking employee satisfaction to customer responses. Journal of Retailing, 84(3), 243-255.

Burnham, T. A., Frels, J. K., \& Mahajan, V. (2003). Consumer switching costs: A typology, antecedents, and consequences. Journal of the Academy of Marketing Science, 31(2), 109-127.

Chang, Y.-H., \& Chen, F.-Y. (2007). Relational benefits, switching barriers, and loyalty: A study of airline customers in Taiwan. Journal of Air Transport Management, 13(2), 104-109. 
Chen P.-T. \& Hu, H.-H. (2010). The effect of relational benefits on perceived value in relation to customer loyalty: An empirical study in the Australian coffee outlets industry. International Journal of Hospitality Management, 29(3), 405-412.

Chou, S., \& Chen, C. W. (2018). The influences of relational benefits on repurchase intention in service contexts: The roles of gratitude, trust and commitment. Journal of Business \& Industrial Marketing, 33(5), 680-692.

Crosby, L. A., Evans, K. R., \& Cowles, D. (1990). Relationship quality in services selling: An interpersonal influence perspective. Journal of Marketing, 54(3), 68-81.

Das, T. K., \& Teng, B.-S. (1998). Between trust and control: Developing confidence in partner cooperation in alliances. Academy of Management Review, 23(3), 491-512.

De Wulf, K., Odekerken-Schröder, G.J., \& Iacobucci, D. (2001). Investments in Consumer Relationships: A Cross-Country and Cross-Industry Exploration. Journal of Marketing, 65(4), 33-50.

Dilsizian, S. E., \& Siegel, E. L. (2014). Artificial intelligence in medicine and cardiac imaging: Harnessing big data and advanced computing to provide personalized medical diagnosis and treatment. Current Cardiology Reports, 16(1), 441.

Emerson, R. M. (1976). Social exchange theory. Annual Review of Sociology, 2, 335-362.

Field, A. (2001). Meta-analysis of correlation coefficients: A Monte Carlo comparison of fixedand random-effects methods. Psychological Methods, 6(2), 161-180.

Fishbein, M., \& Ajzen, I. (1975). Belief, attitude, intention, and behavior: An introduction to theory and research. Reading, MA: Addison-Wesley.

Fournier, S. (1998). Consumers and their brands: Developing relationship theory in consumer research. Journal of Consumer Research, 24(March), 343-373. 
Garbarino. E., \& Johnson, M. S. (1999). The different roles of satisfaction, trust, and commitment in customer relationships. Journal of Marketing, 63(April), 70-87.

Geiger, I., Durand, A., Saab, S., Kleinaltenkamp, M., Baxter, R. \& Lee, Y. (2012). The bonding effects of relationship value and switching costs in industrial buyer-seller relationships: An investigation into role differences. Industrial Marketing Management, 41(1), 82-93.

Geyskens, I., Steenkamp, J.-B. E. M., \& Kumar, N. (1998). Generalizations about trust in marketing channel relationships using meta-analysis. International Journal of Research in Marketing, 15(3), 223-248.

Geyskens, I., Steenkamp, J.-B. E. M., \& Kumar, N. (2006). Make, buy, or ally: A transaction cost theory meta-analysis. Academy of Management Journal, 49(3), 519-543.

Gilly, M. C., \& Zeithaml, V. A. (1985). The elderly consumer and adoption of technologies. Journal of Consumer Research, 12(3), 353-357.

Gil-Saura, I., Ruiz-Molina, M.-E., \& Arteaga-Moreno, F. (2011). Value, supplier dependence, and long-term orientation. Industrial Management \& Data Systems, 111(5), 791-808.

Gremler, D. D., \& Gwinner, K. P. (2015). Relational benefits research: A synthesis. In R. M. Morgan, J. T. Parish, \& G. Deitz (Eds.), Handbook on research in relationship marketing (pp. 32-74). Cheltenham, UK: Edward Elgar Publishing.

Gummesson, E. (1987). The new marketing - Developing long-term interactive relationships. Long Range Planning, 20(4), 10-20.

Gutek, B. A., Bhappu, A. D., Liao-Troth, M. A., \& Cherry, B. (1999). Distinguishing between service relationships and encounters. Journal of Applied Psychology, 84(2), 218-233.

Gwinner, K. P., Gremler, D. D., \& Bitner, M. J. (1998). Relational benefits in services industries: The customer's perspective. Journal of the Academy of Marketing Science, 26(2), 101114. 
Hennig-Thurau, T., Gwinner, K. P., \& Gremler, D. D. (2002). Understanding relationship marketing outcomes: An integration of relational benefits and relationship quality. Journal of Service Research, 4(February), 230-247.

Herr, P. M., Kardes, F. R., and Kim, J. (1991). Effects of word-of-mouth and product-attribute information on persuasion: An accessibility-diagnosticity perspective, Journal of Consumer Research, 17(4), 454-462.

Hogreve, J., \& Gremler, D. D. (2009). Twenty years of service guarantee research: A synthesis. Journal of Service Research, 11(2), 322-343.

Hong, Y., Liao, H., Hu, J., \& Jiang, K. (2013). Missing link in the service profit chain: A metaanalytic review of the antecedents, consequences, and moderators of service climate. Journal of Applied Psychology, 98(2), 237-267.

Hox, J. J. (2010). Multilevel analysis: Techniques and applications. New York: Routledge.

Hult, G. T. M., \& Ferrell, O. C. (2012). A tribute to forty years of top-level marketing research. Journal of the Academy of Marketing Science, 40(1), 1-7.

Hunter, J. E., \& Schmidt, F. L. (2004). Methods of meta-analysis: Correcting error and bias in research findings (2nd ed.). Thousand Oaks, CA: Sage.

Jones, M. A., Mothersbaugh, D. L., \& Beatty, S. E. (2002). Why customers stay: Measuring the underlying dimensions of services switching costs and managing their differential strategic outcomes. Journal of Business Research, 55(6), 441-450.

Kumar, V., \& Reinartz, W. (2016). Creating enduring customer value. Journal of Marketing 80(6), 36-68.

Kumar, V., \& Reinartz, W. (2018). Customer relationship management: Concept, strategy, and tools. Third edition. Springer-Verlag: Berlin, Heidelberg. 
Lam, S. Y., Shankar, V., Erramilli, M. K., \& Murthy, B. (2004). Customer value, satisfaction, loyalty, and switching costs: An illustration from a business-to-business service context. Journal of the Academy of Marketing Science, 32(3), 293-311.

Leinbach-Reyhle, N. (2016). Customer loyalty in today’s modern retail world. Forbes, April 20, 2016, Available at:

https://www.forbes.com/sites/nicoleleinbachreyhle/2016/04/20/customer-loyalty-intodays-modern-retail-world/ (accessed on June 27, 2019).

Lemon, K. N., \& Verhoef, P. C. (2016). Understanding customer experience throughout the customer journey. Journal of Marketing, 80(6), 69-96.

Martin-Ruiz, D., Gremler, D. D., Washburn, J. H., \& Carrión, G. C. (2008). Service value revisited: Specifying a higher-order, formative measure. Journal of Business Research, 61(12), 1278-1291,

McAuley, L., Pham, B., Tugwell, P., \& Moher, D. (2000). Does the inclusion of grey literature influence estimates of intervention effectiveness reported in meta-analysis? The Lancet, $356(9237), 1228-1231$.

Meldrum, J. T., \& Kaczynski, A. T. (2007). Confidence, social, and special treatment benefits as predictors of relationship strength in recreation settings. Leisure/Loisir, 31(1), 325-345.

Meyer-Waarden, L., Benavent, C., \& Castéran, H. (2013). The effects of purchase orientations on perceived loyalty programmes' benefits and loyalty. International Journal of Retail and Distribution Management, 41(3), 201-225.

Moliner, M. A. (2009). Loyalty, perceived value and relationship quality in healthcare services. Journal of Service Management, 20(1), 76-97.

Morgan, R. M., \& Hunt, S. B. (1994). The commitment-trust theory of relationship marketing. Journal of Marketing, 58(July), 20-38. 
Palmatier, R. W., Burke Jarvis, C., Bechkoff, J. R., \& Kardes, F. R. (2009). The role of customer gratitude in relationship marketing. Journal of Marketing, 73(5), 1-18.

Palmatier, R. W., Dant, R. P., Grewal, D., \& Evans, K. R. (2006). Factors influencing the effectiveness of relationship marketing: A meta-analysis. Journal of Marketing, 70(October), 136-153.

Palmatier, R. W., Scheer, L. K., \& Steenkamp, J.-B. E. M. (2007). Customer loyalty to whom? Managing the benefits and risks of salesperson-owned loyalty. Journal of Marketing Research, 44(2), 185-199.

Peterson, R. A., \& Brown, S. P. (2005). On the use of beta coefficients in meta-analysis. Journal of Applied Psychology, 90(1), 175-181.

Peterson, R. A., \& Merunka, D. R. (2014). Convenience samples of college students and research reproducibility. Journal of Business Research, 67(5), 1035-1041.

Pick, D., \& Eisend, M. (2014). Buyers’ perceived switching costs and switching: A metaanalytic assessment of their antecedents. Journal of the Academy of Marketing Science, $42(2), 186-204$

Pick, D., \& Eisend, M. (2016). Customer responses to switching costs: A meta-analytic investigation of the moderating role of culture. Journal of International Marketing, 24(4), $39-60$.

Price, L. L., \& Arnould, E. J. (1999). Commercial friendships: Service provider-client relationships in context. Journal of Marketing, 63(4), 38-56.

Ravald, A., \& Grönroos, C. (1996). The value concept and relationship marketing. European Journal of Marketing, 30(2), 19-30.

Reichheld, F. F. (1996). The loyalty effect. Boston: Harvard Business School Press. 
Ruiz-Molina, M.-E., Gil-Saura, I., \& Moliner-Velazquez, B. (2015). Relational benefits, value, and satisfaction in the relationships between service companies. Journal of Relationship Marketing, 14(1), 1-15.

Sánchez-Fernández, R., \& Iniesta-Bonillo, M. A. (2007). The concept of perceived value: A systematic review of the research. Marketing Theory, 7(4), 427-451.

Scheer, L. K. (2012). Trust, distrust, and confidence in B2B relationships. In G. L. Lilien \& R. Grewal (Eds.), Handbook on business-to-business marketing (pp. 332-347). Cheltenham: Edward Elgar Publishing.

Scheer, L. K., Miao, C. F. \& Garrett, J. (2010). The effects of supplier capabilities on industrial customers' loyalty: The role of dependence. Journal of the Academy of Marketing Science, 38(1), 90-104.

Scheer, L. K., Miao, C. F., \& Palmatier, R. W. (2015). Dependence and interdependence in marketing relationships: Meta-analytic insights. Journal of the Academy of Marketing Science, 43(6), 694-712.

Scheer, L. K., \& Stern, L. W. (1992). The effect of influence type and performance outcomes on attitude toward the influencer. Journal of Marketing Research, 29(February), 128-42.

Steinhoff, L., \& Palmatier, R. W. (2016). Understanding loyalty program effectiveness: Managing target and bystander effects. Journal of the Academy of Marketing Science, 44(1), 88-107.

Sweeney, J. C., \& Webb, D. (2002). Relationship benefits: An exploration of buyer-supplier dyads. Journal of Relationship Marketing, 1(2), 77-92.

Ulaga, W., \& Eggert, A. (2006). Relationship value and relationship quality: Broadening the nomological network of business-to-business relationships. European Journal of Marketing, 40(3/4), 311-327. 
Van Vaerenbergh, Y., Hazée, S. \& Costers, A. (2018). Customer participation in service recovery: A meta-analysis. Marketing Letters, 29(4), 465-483.

Vargo, S. L., \& Lusch, R. F. (2004). Evolving to a new dominant logic for marketing. Journal of Marketing, 68(1), 1-17.

Verma, V., Sharma, D., \& Sheth, J. (2016). Does relationship marketing matter in online retailing? A meta-analytic approach. Journal of the Academy of Marketing Science, 44(2), 206-217.

Villanueva, J., Yoo, S., \& Hanssens, D. M. (2008). The impact of marketing-induced versus word-of-mouth customer acquisition on customer equity growth. Journal of Marketing Research, 45(1), 48-59.

Watson, G. F., Beck, J. T., Henderson, C. M., \& Palmatier, R. W. (2015). Building, measuring, and profiting from customer loyalty. Journal of the Academy of Marketing Science, 43(6), 790-825.

Wetzel, H. A., Hammerschmidt, M., \& Zablah, A. R. (2014). Gratitude versus entitlement: A dual process model of the profitability implications of customer prioritization. Journal of Marketing, 78(2), 1-19.

Zablah, A. R., Franke, G. R., Brown, T. J., \& Bartholomew, D. E. (2012). How and when does customer orientation influence frontline employee job outcomes? A meta-analytic evaluation. Journal of Marketing, 76(May), 21-40.

Zeithaml, V. A. (1988). Consumer perceptions of price, quality, and value: A means-end model and synthesis of evidence. Journal of Marketing, 52(July), 2-22.

Zinkhan, G. M. (2005). Scientific status and knowledge use: Two perspectives. Journal of the Academy of Marketing Science, 33(Summer), 251-253. 
Construct

Confidence

benefits

Definition

Customers' feelings of reduced anxiety and confidence in the service provider that result from being loyal to the organization. (Gwinner et al. 1998)

Social Level of fraternization and personal friendship

benefits between a customer and an employee, and/or the level of personal recognition by employees that result from being loyal to the organization. (Gwinner et al. 1998)

Special The amount of special deals, time savings,

treatment additional services, and/or preferential

benefits treatment that result from being loyal to the organization. (Gwinner et al. 1998)

Perceived The customer's overall assessment of the utility

value of a relationship with a service provider based on perceptions of the benefits received and the costs incurred. (Zeithaml 1988)

Relationship Overall assessment of the strength of a quality relationship. (Crosby et al. 1990)

costs

Perceived, anticipated, and/or experienced costs of switching a relationship from one service provider to another. (Pick and Eisend 2014) purchase intentions and behaviors that systematically favor one service provider over
competing providers. (Watson et al. 2015)

Includes the anticipated costs associated with losing friendly and comfortable of Includes customers' desire to stay in a relationship and considering the organization as their first preference, a willingness to purchase again from the organization in the future, and/or frequent and recent purchase from the organization.

Includes customers having confidence that the service will be performed

correctly, knowing what to expect when dealing with an organization, and perceiving less risk that something will go wrong based on their previous interactions with an organization.

Includes customers being recognized and known by name by certain employees, and being familiar or even friends with the employees who perform the service.

Includes getting discounts, special deals, better prices, gifts, free products and services, preferential treatment, special communications or reports, faster service or other time savings, or special additional services because of the status as a loyal customer.

Includes customers' overall belief that they gain more from the current organization in comparison with their own investment. Customers receiving good products, services, and other gains in comparison with the time, effort, and money they have invested perceive good value.

ncludes customers' overall assessment of a relationship, based on relationship satisfaction, trust, and commitment, or a combination of these.

Includes changes in the number of services bought from a certain organization, and/or changes in the amount of money spent on a certain organization.

\section{Common aliases}

Functional benefits*, psychological benefits, trust benefits, competence benefits

Social bonds, interpersonal relationships, social rewards

Economic benefits, preferential treatment, functional benefits*, customization benefits, financial bonds Utilitarian value, perceived value, economic value

Relationship satisfaction, cumulative satisfaction, affective commitment, trust, relationship strength

Switching barriers, calculative commitment, relationship termination costs

Repurchase intention, company loyalty, buying behavior, attitudinal loyalty, behavioral loyalty, customer retention

Sales, share of wallet, share of purchases, additional purchases, cross-buying $\begin{array}{ll}\text { Firm sales } & \text { Service provider performance enhancemen } \\ \text { performance } & \text { including sales, share of wallet, or other }\end{array}$ changes to the provider's business. (Palmatier et al. 2006)

Note: Synonyms marked with an asterisk $(*)$ are classified as one of these relational benefits according to the content of the measurement items in that study. 
Table 2: Meta-analytic correlations among relational benefits and their consequences

\begin{tabular}{lllllllll} 
& 1. & 2. & 3. & 4. & 5. & 6. & 7. & 8. \\
\hline 1. Confidence benefits & {$[.84]$} & & & & & & & \\
2. Social benefits & .51 & {$[.86]$} & & & & & & \\
3. Special treatment benefits & .52 & .55 & {$[.85]$} & & & & & \\
4. Perceived value & .61 & .56 & .45 & {$[.82]$} & & & & \\
5. Switching costs & .36 & .33 & .30 & .30 & {$[.82]$} & & & \\
6. Relationship quality & .65 & .56 & .49 & .76 & .39 & {$[.87]$} & & \\
7. Customer loyalty & .57 & .47 & .40 & .61 & .39 & .71 & {$[.84]$} & \\
8. Firm sales performance & .46 & .28 & .21 & .36 & .35 & .52 & .60 & {$[.85]$} \\
\hline
\end{tabular}

Notes: Sample size-weighted, reliability-corrected correlation are reported. All correlations are significant at $p<$ .001 . Entries on the diagonal are weighted mean reliability coefficients. The harmonic mean of the cumulative sample sizes across all relationships is 11,633. Full results of the pairwise analyses can be found in Web Appendix E. 


\section{Table 3: Mediation analysis}

$\begin{array}{llcc}\text { Relationship } & \text { Indirect effect via: } & \begin{array}{c}\text { Test } \\ \text { of: }\end{array} & \begin{array}{c}\text { Indirect } \\ \text { effect }\end{array} \\ \text { Mediation? }\end{array}$

Note: ${ }^{* * *} p<.001{ }^{\text {n.s. }}$ not significant. One-tailed tests of significance. 
Table 4: Moderator analyses results

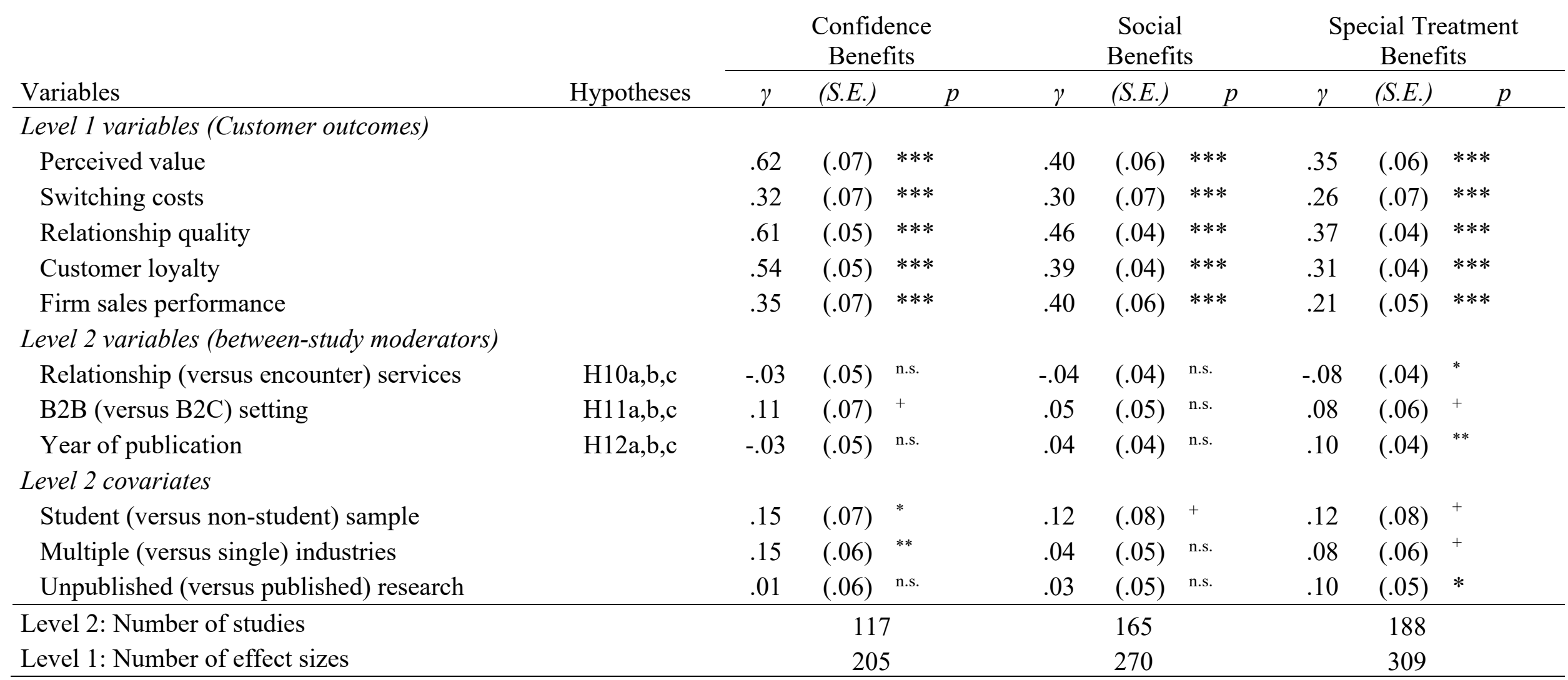

Notes: ${ }^{* * *} p<.001 .{ }^{* *} p<.01 .{ }^{*} p<.05 .{ }^{+} p<.10{ }^{\text {n.s. }}$ not significant. One-tailed tests of significance. 


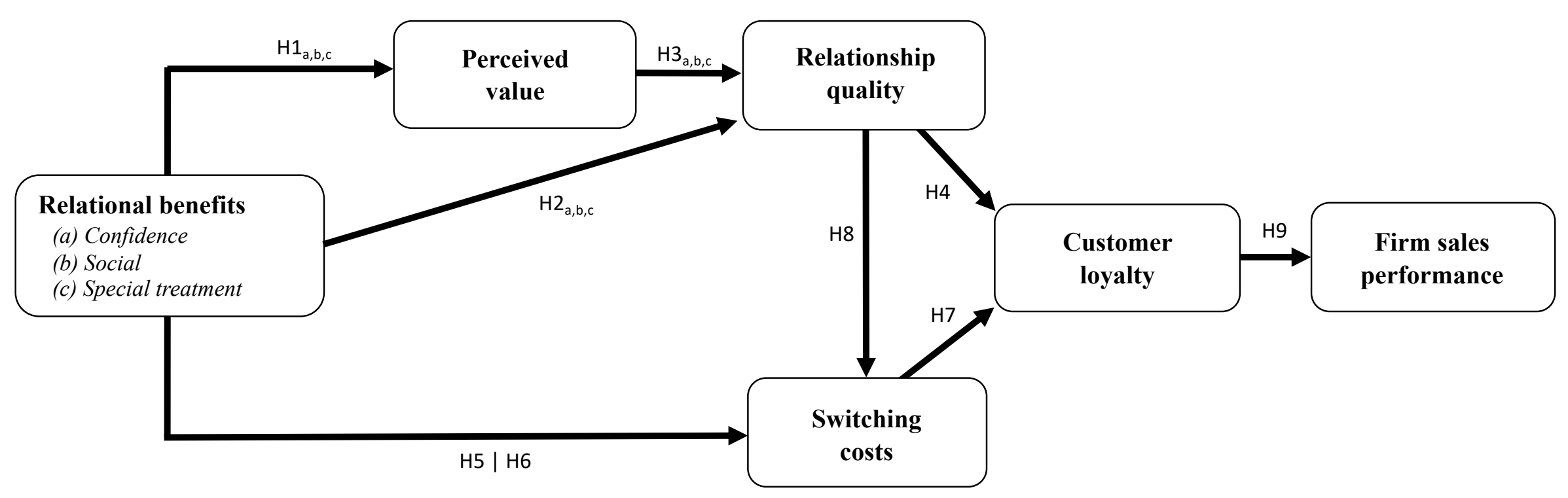


Figure 2: Path model results

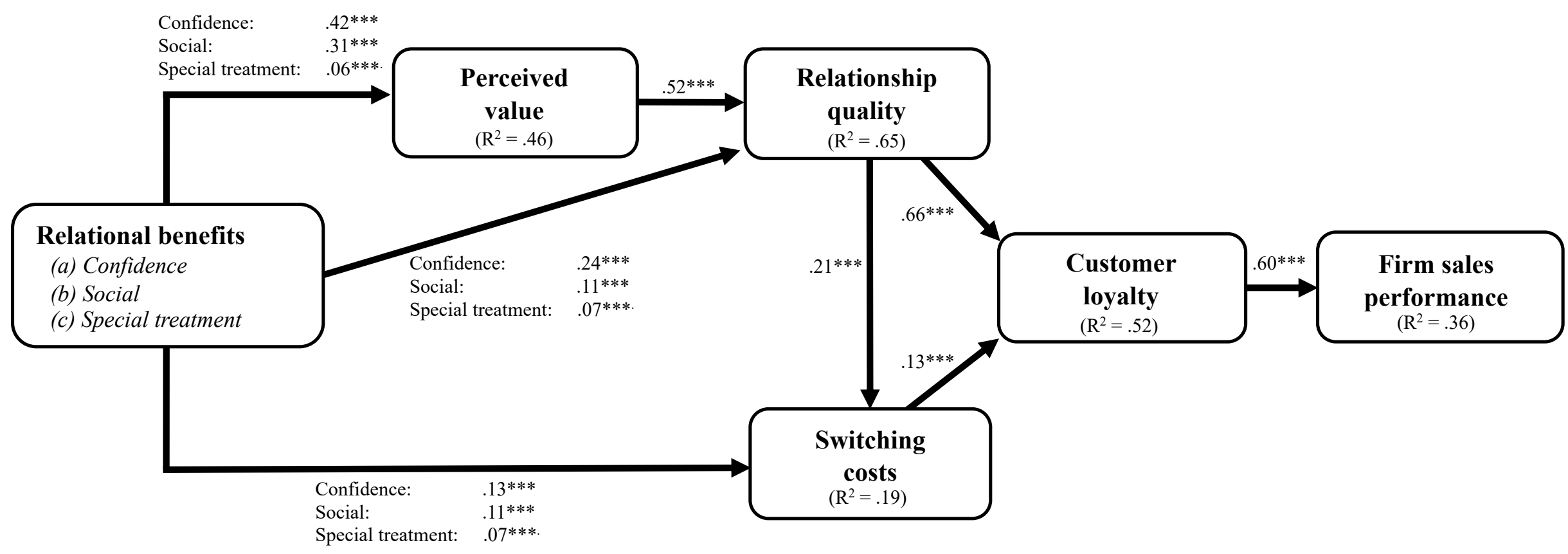

Notes: $* * * p<.001$ 


\section{WEB APPENDIX:}

\section{Understanding and Managing Customer Relational Benefits in Services:}

\section{A Meta-Analysis}

Web Appendix A: List of journals manually searched

Web Appendix B: List of papers included in the meta-analysis

p. 3

Web Appendix C: Sample statistics

Web Appendix D: Breakdown of type of benefits studied in literature

Web Appendix E: Coding of moderators and control variables

Web Appendix F: Study characteristics 


\section{Web Appendix A: List of journals manually searched*}

European Journal of Marketing

Journal of Business Research

Journal of Hospitality and Tourism Research

Journal of Marketing

Journal of Marketing Research

Journal of Relationship Marketing

Journal of Retailing

Journal of Retailing and Consumer Services

Journal of Service Management

Journal of Service Research

Journal of Services Marketing

Journal of the Academy of Marketing Science

Marketing Science

*Note: Articles in our sample appearing in other journals not listed above were found via electronic searches. 


\section{Web Appendix B: List of papers included in the meta-analysis}

Abu Bakar, A. Z. (2013). Dining at continuing care retirement communities: A social interaction view. Doctoral dissertation. Manhattan, KS: Kansas State University.

Ahn, J., Ock, J., Greene, H. \& Rho, T. (2014). The role of friendship in relationship marketing, investigated in the retail service industries. Services Marketing Quarterly, $35(3), 206-221$.

Al-Hawari, M. A. (2014). Emotional stability and switching barriers in the retail banking context. Managing Service Quality, 24(5), 469-486.

Al-Msallam, S. \& Alhadded, A. (2016). The effects of social media marketing in the hotel industry: Conceptual model for development of an effective online community. International Journal of Business and Management Invention, 5(7), 1-12.

Atrek, B., Ozgen, O. \& Kurt, S.D. (2009). Cognitive, affective and conative store loyalty analysis on small and medium sized enterprises: The effects of relational benefits on store loyalty in hairdressers. In Ankara University International Conference on Market, Marketing \& Entrepreneurship. Ankara University, Antalya, Turkey.

Auruskeviciene, V., Salciuviene, L. \& Skudiene, V. (2010). The relationship quality effect on customer loyalty. Pecvnia, 10, 23-36.

Azim, A., Hussain, A., \& Muhammad A. A. (2013). The effect of salesperson trust, preferential treatment \& commitment on customer's loyalty. International Review of Management and Business Research, 2(1), 184-192.

Barry, J. M., \& Doney, P. M. (2011). Cross-cultural examination of relationship quality. Journal of Global Marketing, 24(4), 305-323.

Barry, J., \& Terry, T. S. (2008). Empirical study of relationship value in industrial services. Journal of Business \& Industrial Marketing, 23(4), 228-241. 
Begalle, M. S. (2008). Effectiveness of relationship marketing bonding tactics in predicting customer share in the public sector school foodservice market. Doctoral dissertation, Ames, IA: Iowa State University.

Benner, J. (2010). The airline customer loyalty model. Master dissertation. Copenhagen, Denmark: Copenhagen Business School.

Berenguer-Contrí, G., Ruiz-Molina, M. A., \& Gil-Saura, I. (2009). Relationship benefits and costs in retailing: A cross-industry comparison. Journal of Retail \& Leisure Property, $8(1), 57-66$.

Blazquez-Resino, J. J., \& Golab-Andrzejak, E. (2017). The relational benefits and the quality of services in tourism. Handel Wewnetrzny, 6(371), 18-30.

Bryant, M. D., Hammerschmidt, M., Bauer, H. H., \& Timm, M. (2008). Linking a multicomponent model of commitment to customer profitability. Working paper, University of Mannheim, Germany.

Calvo-Porral, C., Medin, J. A. F., \& Montes-Solla, P. (2016). Relational, functional benefits, and customer value in large retailing: A cross-format comparative analysis. Journal of International Food \& Agribusiness Marketing, 28(2), 132-148.

Campbell, T. T., Nicholson, J. D., \& Kitchen, P. J. (2006). The importance of social bonding and loyalty: An empirical investigation within U.K. private health clubs. Journal of Hospitality \& Leisure Marketing, 14(1), 49-73.

Čater, B. (2008). The importance of social bonds for communication and trust in marketing relationships in professional services. Management, 13(1), 1-15.

Čater, B., \& Čater, T. (2009). Emotional and rational motivations for customer loyalty in business-to-business professional services. Service Industries Journal, 29(8), 1151-1169.

Čater, B., Žabkar, V., \& Čater, T. (2011). Commitment in marketing research services: Two alternative models. Journal of Business Economics and Management. 12(4), 603-628. 
Celuch, K., Robinson, N. M., \& Walsh, A. M. (2015). A framework for encouraging retail customer feedback. Journal of Services Marketing, 29(4), 280-292.

Chae, J.-M. (2012). The effect of relationship benefit on consumer's purchase intention: Focusing on mediating role of interaction. Journal of the Korean Home Economics Association, 50(2), 93-107.

Chai, J. C. Y., Deans, K. R., \& Biggeman, S. (2012). The influence of acculturation on consumer relational bonding in banking relationships. Journal of Strategic Marketing, 20(5), 393-410.

Chai, J. C. Y., Malhotra, N. K, \& Dash, S. (2015). The impact of relational bonding on intention and loyalty: The mediating role of the commitment foci in service relationships. Journal of Hospitality and Tourism Technology, 6(3), 203-227.

Chang, S.-H., Wang, K.-Y., Chih, W.-H., \& Tsai, W.-H. (2012). Building customer commitment in business-to-business markets. Industrial Marketing Management, 41(6), 940-950.

Chang, Y.-H., \& Chen, F.-Y. (2007). Relational benefits, switching barriers and loyalty: A study of airline customers in Taiwan. Journal of Air Transport Management, 13(2), 104109.

Chen, H.-H., \& Gatfield, T. (2011). The effect of expertise of service provider, relational benefit on loyalty-an empirical study of hairstyle franchise system. Journal of International Management Studies, 6(1), 1-7.

Chen, P.-T., \& Hu, H. H. (2010). The effect of relational benefits on perceived value in relation to customer loyalty. An empirical study in the Australian coffee outlets industry. International Journal of Hospitality Management, 29(3), 405-412. 
Chen, T.-Y., Chen, C.-B., \& Tsung, C.-Y. (2007). Promoting relationship selling behaviors to establish relationship value: The case of international airlines. Journal of Relationship Marketing, 5(4), 43-62.

Chen, T.-Y., \& Lin, Y.-H. (2009). Enhancing the relationship benefit to develop relationship value. International Journal of Electronic Customer Relationship Management, 3(2), 167-185.

Chen, Y.-L., \& Chiu, H. C. (2009). The effects of relational bonds on online customer satisfaction. Service Industries Journal, 29(11), 1581-1595.

Cheng, J.-H., Chen, F.-Y. \& Chan, Y.-H. (2008). Airline relationship quality: An examination of Taiwanese passengers. Tourism Management, 29(3), 487-499.

Chih, W.-H., Huang, L.-C., Yang, T.-S., \& Cho, H.-P. (2009). Online relational bond, trust, and customer loyalty. In: 2009 International Conference on Information Management and Engineering, Kuala Lumpur, Malaysia, April 3-5, 138-141.

Chih, W.-H., Lin, Y.-A. \& Lai, H.-C. (2010). The study of antecedents and consequence of relational benefits. Marketing Review (Xing Xiao Ping Lun), 7(3), 357.

Chiu, H.-C., Hsieh, Y.-C., Li, Y.-C., \& Lee, M. (2005). Relationship marketing and consumer switching behavior. Journal of Business Research, 58(12), 1681-1689.

Chiu, Y.-L., Chen, L.-J., Du, J., \& Hsu, Y.-T. (2018). Studying the relationship between the perceived value of online group-buying websites and customer loyalty: The moderating role of referral rewards. Journal of Business \& Industrial Marketing, 11(5), 665-679.

Choi, Y. H., \& Choo, H. J. (2016). Effects of Chinese consumers' relationship benefits and satisfaction on attitudes toward foreign fashion brands: The moderating role of country of salesperson. Journal of Retailing and Consumer Services, 28(January), 99-106. 
Chou, H.-J. (2009). The effect of experiential and relationship marketing on customer value: A case study of international American casual dining chains in Taiwan. Social Behavior and Personality, 37(7), 993-1008.

Chou, S., \& Chen, C.-W. (2018). The influences of relational benefits on repurchase intention in service contexts: The roles of gratitude, trust, and commitment. Journal of Business \& Industrial Marketing, 33(5), 680-692.

Chuang, Y.-F. \& Tai, Y.-F. (2016). Membership-based consumer switching intentions and benefit exchange theory. International Journal of Contemporary Hospitality Management, 28(7), 1361-1390.

Conze, O. (2007). Kundenloyalität durch Kundenvorteile-Segmentspezifische Analyse von Einflussgrößen der Kundenloyalität und Implikationen für das Management von Kundenbeziehungen. Doctoral Dissertation, St. Gallen, Switzerland: University of St. Gallen.

Conze, O., Bieger, T., Laesser, C. \& Riklin, T. (2010). Relationship intention as a mediator between relational benefits and customer loyalty in the tour operator industry. Journal of Travel \& Tourism Marketing, 27(1), 51-62.

Cui, Y. Y., \& Coenen, C. (2016). Relationship value in outsourced FM services - value dimensions and drivers. Facilities, 34(1/2), 43-68.

Dagger, T. S., David, M. E. \& Ng, S. (2011). Do relationship benefits and maintenance drive commitment and loyalty? Journal of Services Marketing, 25(4), 273-281.

Dagger, T. S., \& O’Brien, T. K. (2010). Does experience matter? Differences in relationship benefits, satisfaction, trust, commitment and loyalty for novice and experienced service users. European Journal of Marketing, 44(9/10), 1528-1552. 
Dash, S., Bruning, E., \& Guin, K.K. (2009). A cross-cultural comparison of individualism's moderating effect on bonding and commitment in banking relationships. Marketing Intelligence \& Planning, 27(1), 146-169.

De Wulf, K., \& Odekerken-Schröder, G. (2003). Assessing the impact of a retailer's relationship efforts on consumers' attitudes and behavior. Journal of Retailing and Consumer Services, 10(2), 95-108.

De Wulf, K., Odekerken-Schröder, G. \& Lacobucci, D. (2001). Investments in consumer relationships: A cross-country and cross-industry exploration. Journal of Marketing, 65(4), 33-50.

De Wulf, K., Odekerken-Schröder, G. \& van Kenhove, P. (2003). Investments in consumer relationships: A critical reassessment and model extension. The International Review of Retail, Distribution and Consumer Research, 13(3), 245-261.

Dimitriadis, S. (2010). Testing perceived relational benefits as satisfaction and behavioral outcomes drivers. International Journal of Bank Marketing, 28(4), 297-313.

Dimitriadis, S., \& Tsimonis, G. (2009). Exploring the relative importance of customers' perceived relationship benefits and costs in the context of an e-service. In Biennial International Conference on Services Marketing. Thessaloniki, Greece.

Doaei, H., Rezaei, A. \& Khajei, R. (2011). The impact of relationship marketing tactics on customer loyalty: The mediation role of relationship quality. International Journal of Business Administration, 2(3), 83-93.

Doney, P. M., Barry, J. M., \& Abratt, R. (2007). Trust determinants and outcomes in global B2B services. European Journal of Marketing, 41(9/10), 1096-1116.

Ekasari, T. (2014). Pengaruh kepuasan pelanggan secara keseluruhan sebagai pemediasi pada manfaat relasional terhadap loyalitas. Master Dissertation, Depok, Indonesia: Atma Jaya Yogyakarta University. 
El Fadil, M. N. A. (2009). Customer equity: An approach to nurturing business-to-consumer relationships in banking services. Doctoral dissertation, University of Khartoum, Sudan. Evanschitzky, H., Malhotra, N., von Wangenheim, F., \& Lemon, K. N. (2017). Antecedents of peripheral services cross-buying behavior. Journal of Retailing and Consumer Services, 36(May), 218-224.

Evanschitzky, H., Ramaseshan, B., Woisetschläger, D. M., Richelsen, V., Blut, M., \& Backhaus, C. (2012). Consequences of customer loyalty to the loyalty program and to the company. Journal of the Academy of Marketing Science, 40(5), 625-638.

Feng, N., Zhang, M., \& Tang, S. (2010). Impact of loyalty programs on relationship benefits and customer loyalty: A customer perspective. In: International Conference on Management Science and Engineering. Melbourne, Australia: IEEE.

Feng, X., \& Zhang, M. (2009). Impact of personality traits on perception of relational benefits: An empirical study in service context. In: International Conference on Information Science and Engineering. Nanjing, China: IEEE.

Feng, X., Zhang, M. \& Ye, J. (2015). Empirical study of the influence of consumer relationship proneness on customer loyalty in service context. International Journal of $u$ and e-Service, Science and Technology, 8(4), 195-206.

Fernández-Sabiote, E., \& Román, S. (2016). The multichannel customer's service experience: Building satisfaction and trust. Service Business, 10(2), 423-445.

Gao, H., \& Liu, D. (2014). Relationship of trustworthiness and relational benefit in electronic catalog markets. Electronic Markets, 24(1), 67-75.

Gil-Saura, I., \& Ruiz-Molina, M. E. (2009a). Customer segmentation based on commitment and ICT use. Industrial Management \& Data Systems, 109(2), 206-223.

Gil-Saura, I., \& Ruiz-Molina, M. E. (2009b). Retail customer segmentation based on relational benefits. Journal of Relationship Marketing, 8(3), 253-266. 
Gil-Saura, I., Ruiz-Molina, M. E., \& Arteaga-Moreno, F. (2011). Value, supplier dependence and long-term orientation: Outcomes for B2B commerce in the travel industry. Industrial Management \& Data Systems, 111(5), 791-808.

Gil-Saura, I., Ruiz-Molina, M. E., \& Berenguer-Contrí, G. (2008). Benefits and costs in the relationship between retailers and consumers: A cross-industry comparison. Universia Business Review, 18(1), 40-53.

Gil-Saura, I., Ruiz-Molina, M. E., \& Moliner-Velázquez, B. (2009). Value creation and satisfaction in relationships between service businesses. Working Paper. Valencia, Spain: University of Valencia.

Gounaris, S. P. (2005). Trust and commitment influences on customer retention: Insights from business-to-business services. Journal of Business Research, 58(2), 126-140.

Graça, S. S., Barry, J. M., \& Doney, P. M. (2016). B2B commitment building in emerging markets: The case of Brazil. Journal of Personal Selling \& Sales Management, 36(2), 105-125.

Gu, R., Oh, L.-B., \& Wang, K. (2016). Developing user loyalty for social networking sites: A relational perspective. Journal of Electronic Commerce Research, 17(1), 1-21.

Gwinner, K. P, Gremler, D. D., \& Bitner, M. J. (1998). Relational benefits in services industries: The customer's perspective. Journal of the Academy of Marketing Science, $26(2), 101-114$

Ha, S., \& Stoel, L. (2008). Promoting customer-retailer relationship building: Influence of customer trustworthiness of customer loyalty program marketing. Journal of Customer Behaviour, 7(3), 215-229.

Han, H., \& Kim, W. (2009). Outcomes of relational benefits: Restaurant customers' perspective. Journal of Travel \& Tourism Marketing, 26(8), 820-835. 
Haneef, Z., Rizvi, S. H. R., Madni, H. A., Khakwani, A., \& Rizwan, M. (2014). Customer loyalty of Nokia mobiles: An empirical study conducted in Pakistan. Journal of Sociological Research, 5(1), 405-429.

Hassabala, A. H. A., Attico, Y. T. A., \& Khafela, A. H. (2015). Relationship quality and customers retention in Sudanese banking industry: The moderating role of the relationship benefits. Banking \& Financial Issues, 25(1), 9-29.

Hegner, S. M., Beldad, A. D., \& Langenhorts, N. K. (2016). Here's one for the next show: The influence of four marketing tactics on consumer relationships in the performing arts. Arts and the Market, 6(1), 52-67.

Heidarzadeh Hanzaee, K., \& Alinejad, S. (2012). Service experience influence on generating positive word-of-mouth. Research Journal of Applied Sciences, Engineering and Technology, 4(24), 5609-5616.

Heidarzadeh Hanzaee, K., \& Farzaneh, S. (2012). Exploring the role of personality traits and perceived expertise as antecedents of relationship marketing in service context. Research Journal of Applied Sciences, Engineering and Technology, 4(19), 3727-3731.

Hennig-Thurau, T., Gwinner, K. P., \& Gremler, D. D. (2002). Understanding relationship marketing outcomes: An integration of relational benefits and relationship quality. Journal of Service Research, 4(3), 230-247.

Huang, C.-C., Fang, S.-C., Huang, S.-M., Chang, S.-C., \& Fang, S.-R. (2014). The impact of relational bonds on brand loyalty: The mediating effect of brand relationship quality. Managing Service Quality, 24(2), 184-204.

Huang, E., \& Yen, Y.-R. (2008). Examine the importance of relationship commitment and trust in virtual community. Proceedings of the $7^{\text {th }}$ WSEAS International Conference on EActivities, Cairo, Egypt, 68-73. 
Huang, M.-H. (2015). The influence of relationship marketing investments on customer gratitude in retailing. Journal of Business Research, 68(6), 1318-1323.

Hur, W.-M., Park, J., \& Kim, M. (2010). The role of commitment on the customer benefitsloyalty relationship in mobile service industry. Service Industries Journal, 30(14), 2293 2309.

Jahroni, T. H. D. (2014). Pengaruh relational benefit terhadap kepuasan dalam penjualan online produk batik pada usaha mikro, kecil dan menengah di jawa timur. Ebis, 6(2), 158177.

Jang, J., Kim, S., Lee, Y., \& Kim, J. (2013). The effects of relationship benefit on relationship quality and store loyalty from convergence environments - NPS analysis and moderating effects. Electronic Commerce Research, 13(3), 291-315.

Jin, N., Lee, S., \& Gopalan, R. (2012). How do individual personality traits (D) influence perceived satisfaction with service for college students (C) in a casual restaurant setting (I)?: The CID framework. Journal of Hospitality Marketing \& Management, 21(6), 591616.

Joseph, M. S., \& Unnikrishnan, A. (2016). Relationship bonding strategies and customer retention: A study in business to business context. In: International Conference on Emerging trends in Engineering \& Management, Peshawar, Pakistan, 38-44.

Jun, F. (2009). Research on e-service quality, customer relational benefits and customer satisfaction. In: International Conference on Service Systems and Service Management. Xiamen, China: IEEE.

Kananukul, C., Jung, S., \& Watchravesringkan, K. (2015). Building customer equity through trust in social networking sites: A perspective from Thai consumers. Journal of Research in Interactive Marketing, 9(2), 148-166. 
Kang, J., Alejandro, T. B., \& Groza, M. D. (2015a). Customer-company identification and the effectiveness of loyalty programs. Journal of Business Research, 68(2), 464-471.

Kang, M., Gao, Y., Wang, T., \& Wang, M. (2015b). The role of switching costs in O2O platforms: Antecedents and consequences. International Journal of Smart Home, 9(3), 135-150.

Kang, M., \& Shin, D.-H. (2016). The effect of customers' perceived benefits on virtual brand community loyalty. Online Information Review, 40(3), 298-315.

Kayeser Fatima, J., \& Razzaque, M. A. (2013). Roles of customer involvement in rapport and satisfaction. Asia Pacific Journal of Marketing and Logistics, 25(3), 452-471.

Keeling, K., McGoldrick, P., \& Beatty, S. (2007). Virtual onscreen assistants: A viable strategy to support online customer relationship building? In $34^{\text {th }}$ Association for Consumer Research European Conference, Milan, Italy.

Kim, H.-S., Park, J. Y., \& Jin, B. (2008). Dimensions of online community attributes: Examination of online communities hosted by companies in Korea. International Journal of Retail and Distribution Management, 36(10), 812-830.

Kim, H.-Y. (2007). Toward customer love: investigating the antecedents and outcomes of satisfied customers' emotional attachments to retailers. Doctoral Dissertation, Knoxville, TN: University of Tennessee.

Kim, I., Jeon, S. M., \& Hyun, S. S. (2011). The role of effective service provider communication style in the formation of restaurant patrons' perceived relational benefits and loyalty. Journal of Travel \& Tourism Marketing, 28(7), 765-786.

Kim, M., Kim, B., \& Oh, S. (2018). Relational benefit on satisfaction and durability in strategic corporate social responsibility. Sustainability, 10(4): 1104. 
Kim, S., \& Lee, J. S. (2013). Is satisfaction enough to ensure reciprocity with upscale restaurants? The role of gratitude relative to satisfaction. International Journal of Hospitality Management, 33(June), 118-128.

Kim, W. (2009). Customers' responses to customer orientation of service employees in fullservice restaurants: A relational benefits perspective. Journal of Quality Assurance in Hospitality \& Tourism, 10(3), 153-174.

Kim, W., \& Ok, C. (2009). The effects of relational benefits on customers' perception of favorable inequity, affective commitment, and repurchase intention in full-service restaurants. Journal of Hospitality \& Tourism Research, 33(2), 227-244.

Kim, W., Ok, C., \& Gwinner, K. P. (2010). The antecedent role of customer-to-employee relationships in the development of customer-to-firm relationships. The Service Industries Journal, 30(7), 1139-1157.

Kim, W. G., Lee, Y.-K., \& Yoo, Y.-J. (2006). Predictors of relationship quality and relationship outcomes in luxury restaurants. Journal of Hospitality \& Tourism Research, $30(2), 143-169$.

Kinard, B. R., \& Capella, M. L. (2006). Relationship marketing: The influence of consumer involvement on perceived service benefits. Journal of Services Marketing, 20(6/7), 359368.

Kong, Q., \& Liang, X. Q. (2012). The research on structural path between relationship benefits and relationship outcomes in customer loyalty programs: Using data mining. Advanced Materials Research, 457/458, 1118-1121.

Kong, Q., \& Zhang, M. (2011). The integrative structure and outcome model of relationship benefits: Using data mining. Journal of Software, 6(1), 48-55. 
Kong, Q., Zhang, M., \& Wang, W. (2009). The research of relationship benefits outcomes model in services markets. In: International Conference on Management Science and Engineering. Moscow, Russia: IEEE.

Koritos, C., Koronios, K., \& Stathakopoulos, V. (2014). Functional vs relational benefits: What matters most in affinity marketing? Journal of Services Marketing, 28(4), 265-275.

Krolikowska-Adamczyk, E. (2013). Social bonds in clients' business relationships with professional service providers. Doctoral dissertation, London, U.K., University of Greenwich.

Kuenzel, S., \& Krolikowska, E. (2008a). Psychological bonds and their impact on behavioral loyalty in auditor-client relationships. Managerial Auditing Journal, 23(4), 328-344.

Kuenzel, S., \& Krolikowska, E. (2008b). The effect of bonds on loyalty towards auditors: The mediating role of commitment. Service Industries Journal, 28(5), 685-700.

Lacey, R. (2007). Relationship drivers of customer commitment. Journal of Marketing Theory and Practice, 15(4), 315-333.

Lacey, R., Suh, J., \& Morgan, R. M. (2007). Differential effects of preferential treatment levels on relational outcomes. Journal of Service Research, 9(3), 241-256.

Lai, C.-S., Chen, C.-S., \& Lin, P.-J. (2007). The effects of service quality on customer relational benefits in travel website. In: Portland International Conference on Management of Engineering \& Technology. Portland, OR: IEEE, 1133-1140.

Lee, J.-S., Kim, S., \& Pan, S. (2014a). The role of relationship marketing investments in customer reciprocity. International Journal of Contemporary Hospitality Management, 26(8), 1200-1224.

Lee, J.-S., Pan, S., Tsai, H. (2013). Examining perceived betrayal, desire for revenge and avoidance, and the moderating effect of relational benefits. International Journal of Hospitality Management, 32(March), 80-90. 
Lee, J.-S., Tsang, N., \& Pan, S. (2015a). Examining the differential effects of social and economic rewards in a hotel loyalty program. International Journal of Hospitality Management, 49(August), 17-27.

Lee, Y.-K., Ahn, W.-K., \& Kim, K. (2008). A study on the moderating role of alternative attractiveness in the relationship between relational benefits and customer loyalty. International Journal of Hospitality \& Tourism Administration, 9(1), 52-70.

Lee, Y.-K., Choi, B.-H., Kim, D. J., \& Hyun, S. S. (2014b). Relational benefits, their consequences, and customer membership types. The Service Industries Journal, 34(3), $230-250$.

Lee, Y.-K., Kim, S., Kim, M.-S., Lee, J.-H., \& Lim, K.-T. (2015b). Relational bonding strategies in the franchise industry: The moderating role of duration of the relationship. Journal of Business \& Industrial Marketing, 30(7), 830-841.

Li, L. (2011). Assessing the relational benefits of logistics services perceived by manufacturers in supply chain. International Journal of Production Economics, 132(1), $58-67$.

Li, X., \& Zhang, M. (2008). Relationship benefit in consumer markets and its role in brand image-brand loyalty chain. In: International Conference on Management Science and Engineering. Long Beach, CA: IEEE.

Liang, C.-J. \& Chen, H.-J. (2009). How to lengthen, deepen, and broaden customer-firm relationships with online financial services? Journal of Financial Services Marketing, 14(3), 218-231.

Lima, M., \& Fernandes, T. (2015). Relationship bonds and customer loyalty: A study across different service contexts. In: International Conference on Exploring Services Science; 201. Porto, Portugal: Springer. 
Lin, L.-Y., \& Lu, C.-Y. (2010). The influence of corporate image, relationship marketing, and trust on purchase intentions: The moderating effects of word-of-mouth. Tourism Review, 65(3), 16-34.

Lin, N.-P., Weng, J. C. M., \& Hsieh, Y.-C. (2003). Relational bonds and customer's trust and commitment - A study on the moderating effects of web site usage. Service Industries Journal, 23(3), 103-124.

Liu, C.-M., Huang, C.-J. \& Chen, M.-L. (2014). Relational benefits, customer satisfaction, and customer loyalty in chain store restaurants. International Journal of Organizational Innovation, 7(1), 46-56.

Luu, N., Viet Ngo, L., \& Cadeaux, J. (2018). Value synergy and value asymmetry in relationship marketing programs. Industrial Marketing Management, 68(January), 165176.

Marinkovic, V., \& Obradovic, V. (2015). Customers' emotional reactions in the banking industry. International Journal of Bank Marketing, 33(3), 243-260.

Martin-Ruiz, D., Gremler, D. D., Washburn, J. H., \& Carrión, G. C. (2008). Service value revisited: Specifying a higher-order, formative measure. Journal of Business Research, 61(12), 1278-1291.

Martin-Consuegra, D., Molina, A., \& Esteban, A. (2006). The customers' perspective on relational benefits in banking activities. Journal of Financial Services Marketing, 10(4), 98-108.

Marzo-Navarro, M., Pedraja-Iglesias, M., \& Rivera-Torres, M.P. (2004). The benefits of relationship marketing for the consumer and for the fashion retailers. Journal of Fashion Marketing \& Management, 8(4), 425-436.

Meng, J., \& Elliott, K. M. (2008). Predictors of relationship quality for luxury restaurants. Journal of Retailing and Consumer Services, 15(6), 509-515. 
Meyer-Waarden, L., Benavent, C., \& Castéran, H. (2013). The effects of purchase orientations on perceived loyalty programmes' benefits and loyalty. International Journal of Retail \& Distribution Management, 41(3), 201-225.

Milan, G. S., Slongo, L. A., Eberle, L., De Toni, D., \& Bebber, S. (2018). Determinants of customer loyalty: A study with customers of a Brazilian bank. Benchmarketing: An International Journal, 25(9), 3935-3950.

Molina, A., Martin-Consuegra, D., \& Esteban, A. (2007). Relational benefits and customer satisfaction in retail banking. International Journal of Bank Marketing, 25(4), 253-71.

Moliner-Velazquez, B., Fuentes-Blasco, M., \& Gil-Saura, I. (2014). Value antecedents in relationship between tourism companies. Journal of Business \& Industrial Marketing, 29(3), 215-226.

Moon, S.-J., \& Bae, H. J. (2013). The effect of relational benefits on customer perception of value, satisfaction, and loyalty in the specialty coffee shop business. Journal of the Korean Society of Food Science and Nutrition, 42(1), 120-128.

Narteh, B., Agbemabiese, G. C., Kodua, P., \& Braimah, M. (2013). Relationship marketing and customer loyalty: Evidence from the Ghanaian luxury hotel industry. Journal of Hospitality Marketing \& Management, 22(4), 407-436.

Nath, P., \& Mukherjee, A. (2012). Complementary effects of relationship bonds in information asymmetry. Journal of Services Marketing, 26(3), 168-180.

Ng, C. Y. N. (2010). A study of the impact of relational benefits and relationship marketing on purchase intention in the lodging industry. Doctoral Dissertation, Stillwater, OK: Oklahoma State University.

Ng, S., David, M. E., \& Dagger, T. S. (2011). Generating positive word-of-mouth in the service experience. Managing Service Quality, 21(2), 133-151. 
Ngobo, P. V. (2004). Drivers of customers' cross-buying intentions. European Journal of Marketing, 38(9/10), 1129-1157.

Njoku, B. P. (2009). The role of emotional relational behaviors on interpersonal consumer service loyalty. Doctoral Dissertation, Cleveland, $\mathrm{OH}$ : Cleveland State University.

Noel, N. M., \& Luckett, M. (2014). The benefits, satisfaction, and perceived value of small business membership in a chamber of commerce. International Journal of Nonprofit and Voluntary Sector Marketing, 19(1), 27-39.

Noor, N. A. M., Perumal, S., \& Goaill, M. M. (2015). The impact of relational marketing bonds on retailers' economic and social satisfaction. Journal of Relationship Marketing, $14(2), 124-151$.

O’Mahony, G. B., Sophonsiri, S., \& Turner, L. W. (2013). The impact of the antecedents of relationship development on Thai and Australian resort hotels guests. International Journal of Hospitality Management, 34(September), 214-226.

Ojeme, M., Robson, A., \& Coates, N. (2018). Investigation the Nigerian small and medium enterprises (SMEs)-banking long-term relationship building. International Journal of Bank Marketing, 36(1), 89-110.

Omar, N. A., Ramly, S. M., Alam, S. S., \& Nazri, M. A. (2015). Assessing the effect of loyalty program benefits in satisfaction-loyalty relationship: Evidence from Malaysia, Jurnal Pengurusan, 43, 145-159.

Padilla, R. S., Milton, S. K., Johnson, L. W., \& Nyadzayo, M. W. (2017). Impact of service value on satisfaction and repurchase intentions in business-to-business cloud computing, Service Science, 9(1), 5-13.

Palaima, T., \& Auruškevičienè, V. (2007). Modeling relationship quality in the parcel delivery services market. Baltic Journal of Management, 2(1), 37-54. 
Palmatier, R. W., Gopalakrishna, S., \& Houston, M. B., (2006). Returns on business-tobusiness relationship marketing investments: Strategies for leveraging profits. Marketing Science, 25(5), 477-493.

Palmatier, R. W., Scheer, L. K., Houston, M. B., Evans, K. R., \& Gopalakrishna, S. (2007a). Use of relationship marketing programs in building customer-salesperson and customerfirm relationships: Differential influences on financial outcomes. International Journal of Research in Marketing, 24(3), 210-223.

Palmatier, R. W., Scheer, L. K., \& Steenkamp, J.-B.E.M. (2007b). Customer loyalty to whom? Managing the benefits and risks of salesperson-owned loyalty. Journal of Marketing Research, 44(May), 185-199.

Park, C.-H., \& Kim, Y.-G. (2003). Identifying key factors affecting consumer purchase behavior in an online shopping context. International Journal of Retail \& Distribution Management, 31(1), 16-29.

Park, C.-H., \& Kim, Y.-G. (2006). The effect of information satisfaction and relational benefit on consumers' online shopping site commitments. Journal of Electronic Commerce in Organizations, 4(1), 70-90.

Park, J., Kim, K., Kim, J., \& Koh, J. (2011). The effect of alternative attractiveness and bonds on continuous usage intention of customers in mobile telecommunication services. Information, 15(11), 3655-3662.

Patterson, P. G., \& Smith, T. (2001a). Modeling relationship strength across service types in an Eastern culture. International Journal of Service Industry Management, 12(2), 90-113.

Patterson, P. G., \& Smith, T. (2001b). Relationship benefits in service industries: A replication in a Southeast Asian context. Journal of Services Marketing, 15(6), 425-443.

Patterson, P. G., \& Smith, T. (2003). A cross-cultural study of switching barriers and propensity to stay with service providers. Journal of Retailing, 79(2), 107-120. 
Paulssen, M., \& Roulet, R. (2017). Social bonding as a determinant of share of wallet and cross-buying behaviour in B2B relationships. European Journal of Marketing, 51(5/6), 1011-1028.

Perveen, R., \& Islam, R. (2015). Effects of customers' relational benefits on development of banking industry: An empirical study on some commercial banks in Hulna City of Bangladesh, Journal of Business and Technology, 10(1), 55-71.

Prado, Paulo H. M. (2004). A avaliação do relacionamento sob a ótica do cliente: um estudo em bancos de varejo. Doctoral Dissertation, São Paulo, Brazil: School of Business Administration of Sao Paulo.

Raciti, M. M., Ward, T., \& Dagger, T. S. (2013). The effect of relationship desire on consumer-to-business relationships. European Journal of Marketing, 47(3/4), 615-634.

Ren, S., \& Zhang, M. (2011). An empirical research in service industry about relations between relationship benefit, customer value and relationship quality. In: International Conference on E-Business and E-Government. Shanghai, China: IEEE.

Ren, S., \& Zhang, M. (2013). Exploring antecedents of relationship benefits. Research Journal of Applied Sciences, Engineering and Technology, 5(16), 4082-4087.

Reynolds, K. E. \& Beatty, S. E. (1999). Customer benefits and company consequences of customer-salesperson relationships in retailing. Journal of Retailing, 75(1), 11-32.

Rodriguez, C. M., \& Wilson, D. T. (2002). Relationship bonding and trust as a foundation for commitment in U.S.-Mexican strategic alliances: A structural equation modeling approach. Journal of International Marketing, 10(4), 53-76.

Ruiz-Molina, M.-E., Gil-Saura, I., \& Berenguer-Contrí, G. (2009a). Relational benefits and loyalty in retailing: an inter-sector comparison. International Journal of Retail \& Distribution Management, 37(6), 493-509. 
Ruiz-Molina, M.-E., Gil-Saura, I., \& Berenguer-Contrí, G. (2009b). Relationship benefits, satisfaction, and loyalty in retailing activities: An intersectorial comparation. Investigaciones Europeas de Direccion y Economia de la Empresa, 15(1), 95-108.

Ruiz-Molina, M.-E., Gil-Saura, I., \& Moliner-Velázquez, B. (2010). The role of information technology in relationships between travel agencies and their suppliers. Journal of Hospitality \& Tourism Technology, 1(2), 144-162.

Ruiz-Molina, M.-E., Gil-Saura, I., \& Moliner-Velázquez, B. (2015). Relational benefits, value, and satisfaction in the relationships between service companies. Journal of Relationship Marketing, 14(1), 1-15.

Ruiz-Molina, M.-E., Gil-Saura, I., Servera-Francés, D. (2017). Innovation as a key to strengthen the effect of relationship benefits on loyalty in retailing. Journal of Services Marketing, 31(2), 131-141.

Ryu, K., \& Lee, J.-S. (2017). Examination of relationship quality, relationship benefits, and customer reciprocity from the perspective of relationship marketing investments. Journal of Hospitality and Tourism Research, 41(1), 66-92.

Salerno, A. (2005). Le rôle de la qualité des pratiques de personnalisation dans la séquence valeur-satisfaction-fidélité à la banque. In: lères Journées de Recherche en Marketing IRIS, Lyon, France: IAE De Lyon.

Salleh, M. C. M. (2014). Islamic relationship marketing practice, customer satisfaction, and retention: A mediation analysis. Australian Journal of Basic and Applied Sciences, 8(5), $51-55$.

Scanlan, L., \& McPhail, J. (2000). Forming service relationships with hotel business travelers: The critical attributes to improve retention. Journal of Hospitality \& Tourism Research, 24(4), 491-513. 
Schakett, T., Flaschner, A., Gao, T., \& El-Ansary, A. (2011). Effects of social bonding in business-to-business relationships. Journal of Relationship Marketing, 10(4), 264-280.

Schumann, J. H., Wünderlich, N. V., \& Evanschitzky, H. (2014). Spillover effects of service failures in coalition loyalty programs: The buffering effect of special treatment benefits. Journal of Retailing, 90(1), 111-118.

Senders, A. (2012). Social media and customer loyalty in the travel trade: A relational benefits perspective. Master Dissertation, Leuven, Belgium: KU Leuven.

Senders, A., Govers, R., \& Neuts, B. (2013). Social media affecting tour operators' customer loyalty. Journal of Travel \& Tourism Marketing, 30(1/2), 41-57.

Shammout, A. B., \& Algharabat, R. S. (2013). An investigation into the determinant of Jordanian customer's loyalty towards travel agencies. International Journal of Marketing Studies, 5(6), 1-11.

Shammout, A. B., Polonsky, M., \& Edwardson, M. (2007). Relational bonds and loyalty: The bonds that tie. In: ANZMAC Conference: 3Rs - Reputation, Responsibility, Relevance. Dunedin, New Zealand, 3359-3365.

Shanka, M. S., \& Buvik, A. (2019). When does relationship exchange matters? Social bonds, trust, and satisfaction. Journal of Business-to-Business Marketing, 26(1), 57-74.

Shin, J.-K., Park, M.-S., \& Moon, M. K. (2015). Do eco-friendly VMD and store reputation increase satisfaction of retail customers? Psychology \& Marketing, 32(12), 1148-1157.

Singh Gaur, S., Xu, Y., Quazi, A., \& Nandi, S. (2011). Relational impact of service providers' interaction behavior in healthcare. Managing Service Quality, 21(1), 67-87.

Sirikit, A. (2004). The dyadic study of relationship quality and loyalty intentions in the Thai telecommunication industry. Working paper, Bangkok, Thailand: Sripatum University's Graduate School of Business Administration. 
Smith, B. (1998). Buyer-seller relationships: Bonds, relationship management, and sex-type. Canadian Journal of Administrative Sciences, 15(1), 76-92.

Song, X., \& Xu, L. (2011). A study on relationship value in e-business. In: International Conference on E-Business and E-Government, Shanghai, China: IEEE.

Spake, D. F., \& Megehee, C. M. (2010). Consumer sociability and service provider expertise influence on service relationship success. Journal of Services Marketing, 24(4), 314-324.

Srihadi, T. F., \& Setiawan, D. (2015). The influence of different level of service characteristics and personal involvement towards consumer relational response behaviors. Procedia-Social and Behavioral Sciences, 210 (December), 378-387.

Su, Q., Li, L., \& Cui, Y. W. (2009). Analysing relational benefits in e-business environment from behavioural perspective. Systems Research and Behavioral Science, 26(2), 129-142. Suárez-Álvarez, L., Vázquez-Casielles, R., \& Díaz-Martín, A. M. (2004). El marketing de relaciones y las nuevas tecnologías de la información y la comunicación: Análisis del caso de las agencias de viaje minoristas. In: XVI Encuentro de Profesores Universitarios de Marketing. Alicante, Spain.

Sweeney, J. C., \& Webb, D. A. (2007). How functional, psychological, and social relationship benefits influence individual and firm commitment to the relationship. Journal of Business \& Industrial Marketing, 22(7), 474-488.

Tai, Y.-N., (2015). Effects of relationship bonding on brand attitudes and customer loyalty in tourism industry. Acta Oeconomica, 65(2), 385-397.

Taleghani, M., Biabani, S., Gilaninia, S., Rahbarinia, S. A., \& Mousavian, S. J. (2011). The relationship between customer satisfaction and relationship marketing benefits. Arabian Journal of Business and Management Review, 1(3), 78-86. 
Tariq, B., Awan, H. M., \& Ghouri, S. (2014). Antecedents of sellers' relationship building efforts in relationship marketing a case of the telecom sector of Pakistan. Pakistan Journal of Commerce \& Social Sciences, 8(3), 680-695.

Terblanche, N. S. (2013). An exploratory study of co-production and its outcomes in the South African do-it-yourself hardware market. Southern African Business Review, 17(3), 218-238.

Tseng, T. H., \& Lee, C. T. (2018). Facilitation of consumer loyalty toward branded applications: The dual-route perspective. Telematics and Informatics, 35(5), 1297-1309.

Vandeputte, A. (2008). Loyaliteitsprogramma's: De relatie tussen het programmaontwerp, de lidmaatschapstevredenheid en de winkelloyaliteit. Master Dissertation, University College Ghent: Ghent, Belgium.

Varela-Neira, C., Vázquez-Casielles, R., \& Iglesias, V. (2010). Lack of preferential treatment: Effects on dissatisfaction after a service failure. Journal of Service Management, 21(1), 45-68.

Vazifeh-Doost, H., \& Noorbakhsh, S. N. (2015). The impact of the relational benefits and commitment on word of mouth in an educational context. International Journal of Physical and Social Sciences, 5(1), 382-397.

Virvilaite, R., Saladiene, V., \& Skindaras, D. (2009). The relationship between price and loyalty in services industry. Engineering Economics, 63(3), 96-104.

Vogel, V., Evanschitzky, H., \& Ramaseshan, B. (2008). Community equity drivers and future sales. Journal of Marketing, 72(6), 98-108.

Wagner, J. \& Benoit, S. (2015). Creating value in retail buyer-vendor relationships: A service-centered model. Industrial Marketing Management, 44(January), 166-179.

Wai, C. H., Lu, T. H., Ngoh, T. B., \& Jin, W. P. (2012). The effects of service quality, relational benefits, perceived value and customer satisfaction towards customer loyalty in 
hair salon industry. Bachelor Dissertation, Petaling Jaya, Malaysia: Universiti Tunku Abdul Rahman.

Wang, C.-H., \& Hsu, L. C. (2012). How do service encounters impact on relationship benefits. International Business Research, 5(1), 98-109.

Wang, W.-H. (2008). The interrelationship of retailer's relationship efforts and consumers' attitude and behavior. Measuring Business Excellence, 12(1), 13-28.

Wang, Y., Hingpo Lo, H., Wu, Z., \& Lu, X. (2005). How relationship benefits drive customer asset of a firm: A theoretical framework and empirical investigation. In: International Conference on Services Systems and Services Management, Vol. 1., Chongqing, China: IEEE.

Wei, Y., McIntyre, F. S., \& Soparnot, R. (2015). Effects of relationship benefits and relationship proneness on relationship outcomes: A three-country comparison. Journal of Strategic Marketing, 23(5), 436-456.

Weng, R.-H., Huang, J.-A., Huang, C.-Y., \& Huang, S.-C. (2010). Exploring the impact of customer relational benefit on relationship commitment in health service sectors. Health Care Management Review, 35(4), 312-323.

Widiana, M. E. (2013). Relation benefit implication for repeating order through online sales application case study Batik SMEs in East Java. IOSR Journal of Business and Management, 11(4), 1-9.

Williams, J. D., Han, S.-L., \& Qualls, W. J. (1998). A conceptual model and study of crosscultural business relationships. Journal of Business Research, 42(2), 135-143.

Wu, L.-W. (2011). Beyond satisfaction: The relative importance of locational convenience, interpersonal relationships, and commitment across service types. Managing Service Quality, 21(3), 240-263. 
Xu, Y., Goedegebuure, R., \& Van der Heijden, B. (2006). Customer perception, customer satisfaction, and customer loyalty within Chinese securities business: Towards a mediation model for predicting customer behavior. Journal of Relationship Marketing, 5(4), 79-104.

Yacout, O. M. (2010). Service quality, relational benefits, and customer loyalty in a nonWestern context. S.A.M. Advanced Management Journal, 75(1), 4-22.

Yang, S., Yu, S. L., \& Bruwer, J. (2018). The effect of relational benefits in loyalty programmes: Evidence from Chinese milk formula customer clubs, Journal of Consumer Behavior, 17(2), 211-220.

Yang, T.-J., Tu, Y.-C., \& Shen, C.-S. (2016). The influences of relationship marketing in the housing brokerage market. International Journal of Commerce and Finance, 2(1), 169176.

Yen, C.-H., Liu, L. L., Chen, C.-Y., \& Lee, T.-Y. (2015). Customer relational benefits and relationship-marketing outcomes: Comparing three transaction types of travel product. Asia Pacific Journal of Tourism Research, 20(2), 171-190.

Yen, D. A., \& Barnes, B. R. (2011). Analyzing stage and duration of Anglo-Chinese businessto-business relationships. Industrial Marketing Management, 40(3), 346-357.

Yen, H. J. R., \& Gwinner, K. P. (2003). Internet retail customer loyalty: The mediating role of relational benefits. International Journal of Service Industry Management, 14(5), 483500.

Yu, X., Nguyen, B., Han, S. Chen, C.-H., \& Li, F. (2015). Electronic CRM and perceptions of unfairness. Information Technology \& Management, 16(4), 351-362.

Yu, T.-W., \& Tung, F.-C. (2013). Investigating effects of relationship marketing types in life insurers in Taiwan. Managing Service Quality, 23(2), 111-130. 
Zhang, R., Li, G., Wang, Z., \& Wang, H. (2016). Relationship value based on customer equity influences on group-buying customer loyalty. Journal of Business Research, 69(9), 38203826.

Zhang, W., Wang, Y., Dong, Y., \& Yao, Z. (2005). Customer relationship activities, relationship quality and relationship benefits: An empirical study in perspective of customers. In: International Conference on Services Systems and Services Management, Vol. 1, Chongqing, China: IEEE. 


\section{Web Appendix C: Sample statistics}

\begin{tabular}{lr}
\hline Total number of papers & 224 \\
Total number of independent samples & 235 \\
& \\
Publication date & 4 \\
Pre-2000 & 85 \\
2000 's & 135 \\
$2010+$ &
\end{tabular}

\section{Publication language}

English

Spanish

Indonesian 2

Korean 2

Other (Dutch, French, German, Portuguese) 4

\section{Publication outlet}

Published papers

$\begin{array}{ll}\text { Marketing journals }^{\mathrm{a}} & 60\end{array}$

$\begin{array}{ll}\text { Service journals }^{\mathrm{b}} & 35\end{array}$

$\begin{array}{ll}\text { Hospitality and Tourism journals }^{\mathrm{c}} & 25\end{array}$

$\begin{array}{ll}\text { Management journals }^{d} & 25\end{array}$

$\begin{array}{lr}\text { Information Technology journals }^{\mathrm{e}} & 18\end{array}$

$\begin{array}{ll}\text { Other journals } & 25\end{array}$

Unpublished papers

$\begin{array}{lr}\text { Conference proceedings } & 19\end{array}$

Doctoral dissertations 9

Bachelor and master dissertations $\quad 5$

Working papers 3

Notes: We asked native speakers of the foreign languages (or people who are very fluent in a particular language) to help coding articles in a different language.

a e.g., Journal of Marketing, Journal of Marketing Research, Journal of the Academy of Marketing Science, International Journal of Research in Marketing

b e.g., Journal of Service Research, Journal of Services Marketing, Journal of Service Management

c e.g., Tourism Management, International Journal of Hospitality Management, Journal of Hospitality \& Tourism Research

d e.g., Journal of Business Research, S.A.M. Advanced Management Journal

e e.g., Electronic Commerce Research, Electronic Markets 
Web Appendix D: Breakdown of type of benefits studied in literature

Absolute Percentage Cumulative frequency of studies frequency

Percentage of samples studying one of the three benefits $30 \%$

Confidence benefits

Social benefits

20

$9 \%$

Special treatment benefits

36

$15 \%$

Percentage of samples studying two of the three benefits

$33 \%$

Confidence benefits + Social benefits

$7 \quad 3 \%$

Confidence benefits + Special treatment benefits

$136 \%$

Social benefits + Special treatment benefits

57

$24 \%$

Percentage of samples studying all three relational benefits

$37 \%$

Confidence benefits + Social benefits + Special treatment benefits

88

$37 \%$ 


\section{Web Appendix E: Coding of moderators and control variables}

\begin{tabular}{ll} 
Moderator & Coding \\
\hline Type of service & $0=$ Encounter services \\
& $1=$ Relationship services
\end{tabular}

\section{Definition}

Captures whether the industry in which the sample was drawn reflects an industry where, overall, customers are served by different employees for each service encounter (e.g., airlines, fast food service) or an industry where, overall, customers are served by the same employee during each service encounter (e.g., hairdressers, doctors). Interactions in encounter services are typically brief and impersonal, whereas interactions in relationship services are typically longer and more personal

\begin{tabular}{|c|c|c|}
\hline Type of market & $\begin{array}{l}0=\mathrm{B} 2 \mathrm{C} \\
1=\mathrm{B} 2 \mathrm{~B}\end{array}$ & $\begin{array}{l}\text { Captures whether the customer in the } \\
\text { sample represents an individual } \\
\text { consumer (B2C), or represents an } \\
\text { organization (B2B) }\end{array}$ \\
\hline $\begin{array}{l}\text { Year of } \\
\text { publication }\end{array}$ & $\begin{array}{l}0=\text { Before } 2009 \\
1=\text { During or after } 2009\end{array}$ & $\begin{array}{l}\text { Captures when the data were collected as } \\
\text { measured by publication year. }\end{array}$ \\
\hline $\begin{array}{l}\text { Number of } \\
\text { industries }\end{array}$ & $\begin{array}{l}0=\text { Single industry } \\
1=\text { Multiple industries }\end{array}$ & $\begin{array}{l}\text { Captures whether the sample was drawn } \\
\text { in a specific industry (e.g., restaurant) or } \\
\text { drawn in multiple industries (e.g., } \\
\text { restaurants, banks, and hotels) }\end{array}$ \\
\hline Type of sample & $\begin{array}{l}0=\text { Non-students } \\
1=\text { Students }\end{array}$ & $\begin{array}{l}\text { Captures whether the data were collected } \\
\text { using students as participants (typically } \\
\text { relatively young and low standard } \\
\text { deviation of average age, and with higher } \\
\text { education), or whether the data were } \\
\text { collected among a sample of participants } \\
\text { that vary more in age and education } \\
\text { levels. }\end{array}$ \\
\hline Publication status & $\begin{array}{l}0=\text { Published } \\
1=\text { Unpublished }\end{array}$ & $\begin{array}{l}\text { Captures whether the paper in which the } \\
\text { study was reported was published in an } \\
\text { academic journal (Published), or was } \\
\text { included in a doctoral dissertation, a } \\
\text { master or bachelor dissertation, in a } \\
\text { conference proceeding, or in a working } \\
\text { paper (Unpublished) }\end{array}$ \\
\hline
\end{tabular}




\section{Web Appendix F: Sample characteristics}

\begin{tabular}{|c|c|c|c|c|c|c|c|c|}
\hline Study (in alphabetical order) & $\begin{array}{c}\text { Sample } \\
\text { size }\end{array}$ & $\begin{array}{c}\text { Confidence } \\
\text { benefits }\end{array}$ & $\begin{array}{c}\text { Social } \\
\text { benefits }\end{array}$ & $\begin{array}{c}\text { Special } \\
\text { treatment } \\
\text { benefits }\end{array}$ & Type of service & Setting & $\begin{array}{c}\text { Publication } \\
\text { status }\end{array}$ & Sample \\
\hline Abu Bakar (2013) & 354 & $\checkmark$ & $\checkmark$ & - & Relationship services & $\mathrm{B} 2 \mathrm{C}$ & Unpublished & Nonstudents \\
\hline Ahn et al. (2014; Beauty care) & 165 & $\checkmark$ & - & - & Relationship services & $\mathrm{B} 2 \mathrm{C}$ & Published & Students \\
\hline Ahn et al. (2014; Restaurant) & 169 & $\checkmark$ & - & - & Encounter services & $\mathrm{B} 2 \mathrm{C}$ & Published & Students \\
\hline Al-Hawari (2014) & 413 & $\checkmark$ & $\checkmark$ & $\checkmark$ & Relationship services & $\mathrm{B} 2 \mathrm{C}$ & Published & Nonstudents \\
\hline Al-Msallam \& Alhaddad (2016) & 207 & $\checkmark$ & $\checkmark$ & $\checkmark$ & Encounter services & $\mathrm{B} 2 \mathrm{C}$ & Published & Nonstudents \\
\hline Atrek et al. (2009) & 152 & $\checkmark$ & $\checkmark$ & $\checkmark$ & Relationship services & $\mathrm{B} 2 \mathrm{C}$ & Unpublished & Nonstudents \\
\hline Auruskeviciene et al. (2010) & 75 & - & $\checkmark$ & $\checkmark$ & Encounter services & $\mathrm{B} 2 \mathrm{~B}$ & Published & Nonstudents \\
\hline Azim et al. (2013) & 209 & - & - & $\checkmark$ & Multiple settings & $\mathrm{B} 2 \mathrm{C}$ & Published & Nonstudents \\
\hline Barry \& Doney (2011) & 202 & - & $\checkmark$ & - & Relationship services & $\mathrm{B} 2 \mathrm{~B}$ & Published & Nonstudents \\
\hline Barry \& Terry (2008) & 202 & $\checkmark$ & - & - & Encounter services & $\mathrm{B} 2 \mathrm{~B}$ & Published & Nonstudents \\
\hline Begalle (2008) & 685 & - & $\checkmark$ & $\checkmark$ & Relationship services & $\mathrm{B} 2 \mathrm{~B}$ & Unpublished & Nonstudents \\
\hline Benner (2010) & 276 & $\checkmark$ & $\checkmark$ & $\checkmark$ & Encounter services & $\mathrm{B} 2 \mathrm{C}$ & Unpublished & Nonstudents \\
\hline $\begin{array}{l}\text { Berenguer-Contri et al. (2009), Gil-Saura \& } \\
\text { Molina (2009a, 2009b); Gil-Saura et al. } \\
\text { (2008), Ruiz-Molina et al. (2009a; 2009b) }\end{array}$ & 400 & $\checkmark$ & $\checkmark$ & $\checkmark$ & Multiple settings & $\mathrm{B} 2 \mathrm{C}$ & Published & Nonstudents \\
\hline Blazquez-Resino \& Golab-Andrzejak (2017) & 451 & $\checkmark$ & $\checkmark$ & $\checkmark$ & Encounter services & $\mathrm{B} 2 \mathrm{C}$ & Published & Nonstudents \\
\hline Bryant et al. (2008) & 695 & - & - & $\checkmark$ & Relationship services & $\mathrm{B} 2 \mathrm{C}$ & Unpublished & Nonstudents \\
\hline Calvo-Porral et al. (2016; Hypermarket) & 181 & $\checkmark$ & - & - & Encounter services & $\mathrm{B} 2 \mathrm{C}$ & Published & Nonstudents \\
\hline Calvo-Porral et al. (2016; Supermarket) & 181 & $\checkmark$ & - & - & Encounter services & $\mathrm{B} 2 \mathrm{C}$ & Published & Nonstudents \\
\hline Campbell et al. (2006) & 442 & - & $\checkmark$ & $\checkmark$ & Relationship services & $\mathrm{B} 2 \mathrm{C}$ & Published & Nonstudents \\
\hline $\begin{array}{l}\text { Čater (2008), Čater \& Čater (2009), Čater et al. } \\
\text { (2011) }\end{array}$ & 150 & $\checkmark$ & $\checkmark$ & $\checkmark$ & Relationship services & $\mathrm{B} 2 \mathrm{~B}$ & Published & Nonstudents \\
\hline Celuch et al. (2015) & 864 & - & $\checkmark$ & - & Relationship services & $\mathrm{B} 2 \mathrm{C}$ & Published & Nonstudents \\
\hline Chae (2012) & 562 & $\checkmark$ & - & $\checkmark$ & Multiple settings & $\mathrm{B} 2 \mathrm{C}$ & Unpublished & Nonstudents \\
\hline
\end{tabular}


Chai et al. (2012, 2015)

Chang \& Chen (2007)

Chang et al. (2012)

Chen \& Gatfield (2011)

Chen \& Chiu (2009)

Chen \& Hu (2010)

Chen \& Lin (2009)

Chen et al. (2007)

Cheng et al. (2008)

Chih et al. (2009)

Chih et al. (2010)

Chiu et al. (2005)

Chiu et al. (2018)

Choi \& Choo (2016; China)

Choi \& Choo (2016; Korea)

Chou (2009)

Chou \& Chen (2018)

Chuang \& Tai (2016)

Conze (2007)

Conze et al. (2010)

Cui \& Coenen (2016)

Dagger \& O'Brien (2010)

Dagger et al. (2011), Ng et al. (2011)

Dash et al. (2009; Canada)

Dash et al. (2009; India)

De Wulf \& Odekerken-Schröder (2003; Belgium)

$\begin{array}{rrrr}368 & - & \checkmark & \checkmark \\ 326 & \checkmark & \checkmark & \checkmark \\ 522 & - & \checkmark & - \\ 257 & - & \checkmark & \checkmark \\ 351 & - & \checkmark & \checkmark \\ 949 & \checkmark & \checkmark & \checkmark \\ 300 & \checkmark & \checkmark & \checkmark \\ 400 & \checkmark & \checkmark & \checkmark \\ 252 & - & \checkmark & - \\ 310 & - & \checkmark & \checkmark \\ 333 & \checkmark & \checkmark & \checkmark \\ 613 & - & \checkmark & \checkmark \\ 403 & - & \checkmark & \checkmark \\ 150 & \checkmark & \checkmark & - \\ 150 & \checkmark & \checkmark & - \\ 327 & - & - & \checkmark \\ 253 & \checkmark & \checkmark & \checkmark \\ 366 & \checkmark & \checkmark & \checkmark \\ 1,703 & \checkmark & \checkmark & \checkmark \\ 1,702 & \checkmark & \checkmark & \checkmark \\ 60 & \checkmark & - & - \\ 376 & \checkmark & \checkmark & \checkmark \\ 591 & \checkmark & \checkmark & \checkmark \\ 126 & - & \checkmark & \checkmark \\ 156 & - & \checkmark & \checkmark \\ 281 & - & - & \checkmark\end{array}$

Relationship services

Encounter services

Relationship services

Relationship services

Encounter services

Encounter services

Encounter services

Encounter services

Encounter services

Encounter services

Relationship services

Relationship services

Encounter services

Encounter services

Encounter services

Encounter services

Multiple settings

Encounter services

Relationship services

Relationship services

Relationship services

Multiple settings

Multiple settings

Relationship services

Relationship services

Encounter services
B2

$\mathrm{B} 2 \mathrm{C}$

$\mathrm{B} 2 \mathrm{~B}$

$\mathrm{B} 2 \mathrm{C}$

$\mathrm{B} 2 \mathrm{C}$

$\mathrm{B} 2 \mathrm{C}$

$\mathrm{B} 2 \mathrm{C}$

B2C

B2C

B2C

$\mathrm{B} 2 \mathrm{C}$

$\mathrm{B} 2 \mathrm{C}$

$\mathrm{B} 2 \mathrm{C}$

$\mathrm{B} 2 \mathrm{C}$

B2C

$\mathrm{B} 2 \mathrm{C}$

$\mathrm{B} 2 \mathrm{C}$

B2C

B2C

B2C

B2B

B2C

B2C

B2B

B2B

B2C
Published

Published

Published

Published

Published

Published

Published

Published

Published

Unpublished

Published

Published

Published

Published

Published

Published

Published

Published

Unpublished

Published

Published

Published

Published

Published

Published

Published
Nonstudents

Nonstudents

Nonstudents

Nonstudents

Nonstudents

Nonstudents

Nonstudents

Nonstudents

Nonstudents

Students

Nonstudents

Nonstudents

Nonstudents

Nonstudents

Nonstudents

Nonstudents

Nonstudents

Nonstudents

Nonstudents

Nonstudents

Nonstudents

Nonstudents

Nonstudents

Nonstudents

Nonstudents

Nonstudents 
De Wulf \& Odekerken-Schröder (2003; The Netherlands)

De Wulf et al. (2001; Belgium - Apparel retail)

De Wulf et al. (2001; Belgium - Food retail)

De Wulf et al. (2001; The Netherlands Apparel retail)

De Wulf et al. (2001; The Netherlands - Food retail)

De Wulf et al. (2001; U.S. - Apparel retail)

De Wulf et al. (2001; U.S. - Food retail)

De Wulf et al. (2003)

Dimitriadis (2010)

Dimitriadis \& Tsimonis (2009)

Doaei et al. (2011)

Doney et al. (2007)

Ekasari (2014)

El Fadil (2009)

Evanschitzky et al. (2012)

Evanschitzky et al. (2017)

Feng \& Zhang (2009)

Feng et al. (2010)

Feng et al. (2015)

Fernández-Sabiote \& Román (2016)

Gao \& Liu (2014)

Gil-Saura et al. (2009, 2011), Moliner-

Vazquez et al. (2014); Ruiz-Molina et al. $(2010,2015)$

$\begin{array}{rrrrcrrr}300 & - & - & \checkmark & \text { Encounter services } & \text { B2C } & \text { Published } & \text { Nonstudents } \\ 302 & - & \checkmark & \checkmark & \text { Encounter services } & \text { B2C } & \text { Published } & \text { Nonstudents } \\ 289 & - & \checkmark & \checkmark & \text { Encounter services } & \text { B2C } & \text { Published } & \text { Nonstudents } \\ 338 & - & \checkmark & \checkmark & \text { Encounter services } & \text { B2C } & \text { Published } & \text { Nonstudents } \\ & & & & & & & \\ 337 & - & \checkmark & \checkmark & \text { Encounter services } & \text { B2C } & \text { Published } & \text { Nonstudents } \\ 230 & - & \checkmark & \checkmark & \text { Encounter services } & \text { B2C } & \text { Published } & \text { Nonstudents } \\ 231 & - & \checkmark & \checkmark & \text { Encounter services } & \text { B2C } & \text { Published } & \text { Nonstudents } \\ 187 & - & \checkmark & \checkmark & \text { Encounter services } & \text { B2C } & \text { Published } & \text { Nonstudents } \\ 209 & \checkmark & \checkmark & \checkmark & \text { Relationship services } & \text { B2C } & \text { Published } & \text { Nonstudents } \\ 444 & \checkmark & \checkmark & \checkmark & \text { Encounter services } & \text { B2C } & \text { Published } & \text { Nonstudents } \\ 125 & - & \checkmark & \checkmark & \text { Relationship services } & \text { B2C } & \text { Published } & \text { Nonstudents } \\ 202 & - & \checkmark & - & \text { Encounter services } & \text { B2B } & \text { Published } & \text { Nonstudents } \\ 205 & \checkmark & \checkmark & \checkmark & \text { Encounter services } & \text { B2C } & \text { Unpublished } & \text { Nonstudents } \\ 195 & - & \checkmark & \checkmark & \text { Relationship services } & \text { B2C } & \text { Unpublished } & \text { Nonstudents } \\ 5,189 & - & \checkmark & \checkmark & \text { Encounter services } & \text { B2C } & \text { Published } & \text { Nonstudents } \\ 5,667 & - & \checkmark & - & \text { Relationship services } & \text { B2C } & \text { Published } & \text { Nonstudents } \\ 131 & \checkmark & \checkmark & \checkmark & \text { Multiple settings } & \text { B2C } & \text { Unpublished } & \text { Students } \\ 172 & \checkmark & \checkmark & \checkmark & \text { Encounter services } & \text { B2C } & \text { Unpublished } & \text { Nonstudents } \\ 269 & \checkmark & \checkmark & \checkmark & \text { Multiple settings } & \text { B2C } & \text { Published } & \text { Nonstudents } \\ 302 & \checkmark & - & - & \text { Relationship services } & \text { B2C } & \text { Published } & \text { Nonstudents } \\ 1,762 & \checkmark & \checkmark & \checkmark & \text { Encounter services } & \text { B2C } & \text { Published } & \text { Nonstudents } \\ 309 & \checkmark & \checkmark & \checkmark & \text { Relationship services } & \text { B2B } & \text { Published } & \text { Nonstudents }\end{array}$


Gounaris (2005)

Graça et al. (2016; Brazil)

Graça et al. (2016; U.S.)

Gu et al. (2016)

Gwinner et al. (1998)

Ha \& Stoel (2008)

Han \& Kim (2009)

Haneef et al. (2014)

Hassabala et al. (2015)

Hegner et al. (2016)

Heidarzadeh Hanzaee \& Alinejad (2012)

Heidarzadeh Hanzaee \& Farzaneh (2012)

Hennig-Thurau et al. (2002)

Huang (2015)

Huang \& Yen (2008)

Huang et al. (2014)

Hur et al. (2010)

Jahroni (2014)

Jang et al. (2013)

Jin et al. (2012)

Joseph \& Unnikrishnan (2016)

Jun (2009)

Kananukul et al. (2015)

Kang \& Shin (2016)

Kang et al. (2015a)

Kang et al. (2015b)

\begin{tabular}{|c|c|c|}
\hline 127 & - & $\checkmark$ \\
\hline 110 & $\checkmark$ & $\checkmark$ \\
\hline 169 & $\checkmark$ & $\checkmark$ \\
\hline 289 & - & - \\
\hline 299 & $\checkmark$ & $\checkmark$ \\
\hline 457 & - & - \\
\hline 340 & $\checkmark$ & $\checkmark$ \\
\hline 150 & $\checkmark$ & - \\
\hline 280 & - & $\checkmark$ \\
\hline 252 & - & - \\
\hline 300 & $\checkmark$ & $\checkmark$ \\
\hline 388 & - & $\checkmark$ \\
\hline 336 & $\checkmark$ & $\checkmark$ \\
\hline 239 & - & - \\
\hline 488 & - & - \\
\hline 524 & - & $\checkmark$ \\
\hline 295 & $\checkmark$ & - \\
\hline 180 & $\checkmark$ & $\checkmark$ \\
\hline 254 & $\checkmark$ & $\checkmark$ \\
\hline 252 & $\checkmark$ & $\checkmark$ \\
\hline 70 & - & $\checkmark$ \\
\hline 259 & $\checkmark$ & $\checkmark$ \\
\hline 207 & $\checkmark$ & $\checkmark$ \\
\hline 200 & - & $\checkmark$ \\
\hline 573 & - & $\checkmark$ \\
\hline & - & - \\
\hline
\end{tabular}

$\begin{array}{cccc}\text { Multiple settings } & \text { B2B } & \text { Published } & \text { Nonstudents } \\ \text { Multiple settings } & \text { B2B } & \text { Published } & \text { Nonstudents } \\ \text { Multiple settings } & \text { B2B } & \text { Published } & \text { Nonstudents } \\ \text { Encounter services } & \text { B2C } & \text { Published } & \text { Students } \\ \text { Multiple settings } & \text { B2C } & \text { Published } & \text { Nonstudents } \\ \text { Encounter services } & \text { B2C } & \text { Published } & \text { Students } \\ \text { Encounter services } & \text { B2C } & \text { Published } & \text { Nonstudents } \\ \text { Encounter services } & \text { B2C } & \text { Published } & \text { Students } \\ \text { Relationship services } & \text { B2C } & \text { Published } & \text { Nonstudents } \\ \text { Relationship services } & \text { B2C } & \text { Published } & \text { Nonstudents } \\ \text { Multiple settings } & \text { B2C } & \text { Published } & \text { Nonstudents } \\ \text { Relationship services } & \text { B2C } & \text { Published } & \text { Nonstudents } \\ \text { Multiple settings } & \text { B2C } & \text { Published } & \text { Nonstudents } \\ \text { Encounter services } & \text { B2C } & \text { Published } & \text { Nonstudents } \\ \text { Encounter services } & \text { B2C } & \text { Unpublished } & \text { Nonstudents } \\ \text { Encounter services } & \text { B2C } & \text { Published } & \text { Students } \\ \text { Encounter services } & \text { B2C } & \text { Published } & \text { Nonstudents } \\ \text { Encounter services } & \text { B2C } & \text { Unpublished } & \text { Nonstudents } \\ \text { Encounter services } & \text { B2C } & \text { Published } & \text { Nonstudents } \\ \text { Encounter services } & \text { B2C } & \text { Published } & \text { Nonstudents } \\ \text { Relationship services } & \text { B2B } & \text { Unpublished } & \text { Nonstudents } \\ \text { Encounter services } & \text { B2C } & \text { Unpublished } & \text { Nonstudents } \\ \text { Encounter services } & \text { B2C } & \text { Published } & \text { Nonstudents } \\ \text { Encounter services } & \text { B2C } & \text { Published } & \text { Nonstudents } \\ \text { Multiple settings } & \text { B2C } & \text { Published } & \text { Nonstudents } \\ \text { Encounter services } & \text { B2C } & \text { Published } & \text { Students }\end{array}$


Kayeser Fatima \& Razzaque (2013)

Keeling et al. (2007)

Kim (2007; Apparel retailer)

Kim (2007; Grocery retailer)

$\operatorname{Kim}(2009)$

Kim \& Lee (2013), Lee et al. (2013, 2014a), Ryu \& Lee (2017)

Kim \& Ok (2009)

Kim et al. (2006)

Kim et al. (2008)

Kim et al. (2010)

Kim et al. (2011)

Kim et al. (2018)

Kinard \& Capella (2006; Fast food)

Kinard \& Capella (2006; Hairdresser)

Kong \& Liang (2012)

Kong \& Zhang (2011)

Kong et al. (2009)

Koritos et al. (2014)

Krolikowska-Adamczyk (2013)

Kuenzel \& Krolikowska (2008a)

Kuenzel \& Krolikowska (2008b)

Lacey (2007; Study 2)

Lacey et al. (2007), Lacey (2007; Study 1)

Lai et al. (2007)

Lee et al. (2008)

Lee et al. (2014b)

\begin{tabular}{|c|c|c|}
\hline 212 & $\checkmark$ & $\checkmark$ \\
\hline 2114 & - & $\checkmark$ \\
\hline 303 & - & $\checkmark$ \\
\hline 301 & - & $\checkmark$ \\
\hline 401 & $\checkmark$ & $\checkmark$ \\
\hline 297 & $\checkmark$ & $\checkmark$ \\
\hline 411 & $\checkmark$ & $\checkmark$ \\
\hline 887 & - & - \\
\hline 351 & - & $\checkmark$ \\
\hline 293 & $\checkmark$ & - \\
\hline 27 & $\checkmark$ & $\checkmark$ \\
\hline 113 & $\checkmark$ & $\checkmark$ \\
\hline 43 & $\sqrt{ }$ & $\checkmark$ \\
\hline 48 & $\checkmark$ & $\checkmark$ \\
\hline 151 & $\checkmark$ & $\checkmark$ \\
\hline 287 & $\checkmark$ & $\checkmark$ \\
\hline 184 & $\checkmark$ & $\checkmark$ \\
\hline 1165 & $\checkmark$ & $\checkmark$ \\
\hline 279 & $\checkmark$ & $\checkmark$ \\
\hline 98 & $\checkmark$ & - \\
\hline 300 & - & $\checkmark$ \\
\hline 639 & $\checkmark$ & $\checkmark$ \\
\hline 2461 & $\checkmark$ & $\checkmark$ \\
\hline 222 & $\checkmark$ & $\checkmark$ \\
\hline 250 & $\checkmark$ & $\checkmark$ \\
\hline 522 & $\sqrt{ }$ & $\checkmark$ \\
\hline
\end{tabular}

Relationship services

Encounter services

Encounter services

Encounter services

Encounter services

Encounter services

Encounter services

Encounter services

Encounter services

Encounter services

Encounter services

Encounter services

Encounter services

Relationship services

Encounter services

Relationship services

Relationship services

Encounter services

Relationship services

Relationship services

Relationship services

Encounter services

Encounter services

Encounter services

Encounter services

Encounter services

$\begin{array}{lcl}\text { B2C } & \text { Published } & \text { Nonstudents } \\ \text { B2C } & \text { Unpublished } & \text { Nonstudents } \\ \text { B2C } & \text { Unpublished } & \text { Nonstudents } \\ \text { B2C } & \text { Unpublished } & \text { Nonstudents } \\ \text { B2C } & \text { Published } & \text { Nonstudents } \\ \text { B2C } & \text { Published } & \text { Nonstudents } \\ & & \\ \text { B2C } & \text { Published } & \text { Nonstudents } \\ \text { B2C } & \text { Published } & \text { Nonstudents } \\ \text { B2C } & \text { Published } & \text { Nonstudents } \\ \text { B2C } & \text { Published } & \text { Nonstudents } \\ \text { B2C } & \text { Published } & \text { Nonstudents } \\ \text { B2C } & \text { Published } & \text { Nonstudents } \\ \text { B2C } & \text { Published } & \text { Nonstudents } \\ \text { B2C } & \text { Published } & \text { Nonstudents } \\ \text { B2C } & \text { Published } & \text { Nonstudents } \\ \text { B2C } & \text { Published } & \text { Nonstudents } \\ \text { B2C } & \text { Unpublished } & \text { Nonstudents } \\ \text { B2C } & \text { Published } & \text { Nonstudents } \\ \text { B2B } & \text { Unpublished } & \text { Nonstudents } \\ \text { B2B } & \text { Published } & \text { Nonstudents } \\ \text { B2B } & \text { Published } & \text { Nonstudents } \\ \text { B2C } & \text { Published } & \text { Nonstudents } \\ \text { B2C } & \text { Published } & \text { Nonstudents } \\ \text { B2C } & \text { Unpublished } & \text { Nonstudents } \\ \text { B2C } & \text { Published } & \text { Nonstudents } \\ \text { B2C } & \text { Published } & \text { Nonstudents } \\ & & \end{array}$


Li (2011)

Li \& Zhang (2008)

Liang \& Chen (2009)

Lima \& Fernandes (2015)

Lin \& Lu (2010)

Lin et al. (2003)

Liu et al. (2014)

Luu et al. (2018)

Marinkovich \& Obradovic (2015)

Martin Ruiz et al. (2008)

Martin-Consuegra et al. (2006)

Marzo-Navarro et al. (2004)

Meng \& Elliot (2008)

Meyer-Waarden et al. (2013; Grocery retail)

Meyer-Waarden et al. (2013; Perfumery)

Milan et al. (2018)

Molina et al. (2007)

Moon \& Bae (2013)

Narteh et al. (2013)

Nath \& Mukherjee (2012)

$\mathrm{Ng}$ (2010)

Ngobo (2004; Bank)

Ngobo (2004; Retail)

Njoku (2009)

\begin{tabular}{|c|c|c|}
\hline 334 & - & $\checkmark$ \\
\hline 496 & - & $\checkmark$ \\
\hline 210 & - & - \\
\hline 228 & $\checkmark$ & - \\
\hline 686 & - & - \\
\hline 233 & $\checkmark$ & $\checkmark$ \\
\hline 458 & - & - \\
\hline 818 & - & $\checkmark$ \\
\hline 267 & $\checkmark$ & $\checkmark$ \\
\hline 113 & - & - \\
\hline 211 & - & $\checkmark$ \\
\hline 739 & $\checkmark$ & - \\
\hline 561 & $\checkmark$ & $\checkmark$ \\
\hline 228 & - & $\checkmark$ \\
\hline 404 & - & - \\
\hline 120 & $\checkmark$ & - \\
\hline 210 & $\checkmark$ & - \\
\hline 505 & - & $\checkmark$ \\
\hline 204 & $\checkmark$ & $\checkmark$ \\
\hline 329 & $\checkmark$ & $\checkmark$ \\
\hline 102 & - & $\checkmark$ \\
\hline 452 & - & $\checkmark$ \\
\hline 328 & $\checkmark$ & $\checkmark$ \\
\hline 257 & - & - \\
\hline 280 & $\checkmark$ & - \\
\hline 204 & - & - \\
\hline
\end{tabular}

$\begin{array}{cccc}\text { Encounter services } & \text { B2C } & \text { Published } & \text { Nonstudents } \\ \text { Relationship services } & \text { B2B } & \text { Published } & \text { Nonstudents } \\ \text { Encounter services } & \text { B2B } & \text { Published } & \text { Nonstudents } \\ \text { Encounter services } & \text { B2C } & \text { Unpublished } & \text { Nonstudents } \\ \text { Encounter services } & \text { B2C } & \text { Published } & \text { Nonstudents } \\ \text { Encounter services } & \text { B2C } & \text { Published } & \text { Nonstudents } \\ \text { Encounter services } & \text { B2C } & \text { Published } & \text { Nonstudents } \\ \text { Relationship services } & \text { B2C } & \text { Published } & \text { Nonstudents } \\ \text { Encounter services } & \text { B2C } & \text { Published } & \text { Students } \\ \text { Multiple settings } & \text { B2B } & \text { Published } & \text { Nonstudents } \\ \text { Relationship services } & \text { B2C } & \text { Published } & \text { Nonstudents } \\ \text { Multiple settings } & \text { B2C } & \text { Published } & \text { Nonstudents } \\ \text { Relationship services } & \text { B2C } & \text { Published } & \text { Nonstudents } \\ \text { Encounter services } & \text { B2C } & \text { Published } & \text { Nonstudents } \\ \text { Encounter services } & \text { B2C } & \text { Published } & \text { Nonstudents } \\ \text { Encounter services } & \text { B2C } & \text { Published } & \text { Nonstudents } \\ \text { Encounter services } & \text { B2C } & \text { Published } & \text { Nonstudents } \\ \text { Relationship services } & \text { B2C } & \text { Published } & \text { Nonstudents } \\ \text { Relationship services } & \text { B2C } & \text { Published } & \text { Nonstudents } \\ \text { Relationship services } & \text { B2C } & \text { Published } & \text { Nonstudents } \\ \text { Encounter services } & \text { B2C } & \text { Published } & \text { Nonstudents } \\ \text { Relationship services } & \text { B2C } & \text { Published } & \text { Nonstudents } \\ \text { Encounter services } & \text { B2C } & \text { Unpublished } & \text { Nonstudents } \\ \text { Relationship services } & \text { B2C } & \text { Published } & \text { Nonstudents } \\ \text { Encounter services } & \text { B2C } & \text { Published } & \text { Nonstudents } \\ \text { Encounter services } & \text { B2C } & \text { Published } & \text { Nonstudents }\end{array}$


Noel \& Lucket (2014)

Noor et al. (2015)

O’Mahony et al. (2013; Australia)

O'Mahony et al. (2013; Thailand)

Ojeme et al. (2018)

Omar et al. (2015)

Padilla et al. (2017)

Palaima \& Auruškevičienè (2007)

Palmatier et al. (2006)

Palmatier et al. (2007a)

Palmatier et al. (2007b; Study 1)

Park \& Kim (2003)

Park \& Kim (2006)

Park et al. (2011)

Patterson \& Smith (2001a, 2001b, 2003)

Paulssen \& Roulet (2017)

Perveen \& Islam (2015)

Prado (2004)

Raciti et al. (2013)

Ren \& Zhang (2011)

Ren \& Zhang (2013)

Reynolds \& Beatty (1999)

Rodriguez \& Wilson (2002; Mexico)

Rodriguez \& Wilson (2002; U.S.)

Ruiz-Molina et al. (2017)

Salerno (2005)

\begin{tabular}{|c|c|c|}
\hline 524 & $\checkmark$ & $\checkmark$ \\
\hline 140 & - & - \\
\hline 299 & $\sqrt{ }$ & - \\
\hline 300 & $\sqrt{ }$ & - \\
\hline 491 & - & $\checkmark$ \\
\hline 300 & - & - \\
\hline 328 & $\checkmark$ & - \\
\hline 200 & $\checkmark$ & $\checkmark$ \\
\hline 313 & - & - \\
\hline 362 & - & - \\
\hline 201 & - & - \\
\hline 602 & $\checkmark$ & - \\
\hline 1,278 & - & - \\
\hline 344 & - & $\checkmark$ \\
\hline 155 & $\checkmark$ & $\checkmark$ \\
\hline 127 & - & $\checkmark$ \\
\hline 262 & $\checkmark$ & $\checkmark$ \\
\hline 480 & $\checkmark$ & $\checkmark$ \\
\hline 334 & $\checkmark$ & $\checkmark$ \\
\hline 193 & $\checkmark$ & $\checkmark$ \\
\hline 297 & $\checkmark$ & - \\
\hline 330 & - & $\checkmark$ \\
\hline 42 & - & $\checkmark$ \\
\hline 42 & - & $\checkmark$ \\
\hline 820 & $\checkmark$ & $\checkmark$ \\
\hline 423 & - & $\checkmark$ \\
\hline
\end{tabular}

Relationship services

Relationship services

Encounter services

Encounter services

Relationship services

Encounter services

Relationship services

Encounter services

Multiple settings

Multiple settings

Multiple settings

Encounter services

Encounter services

Encounter services

Multiple settings

Relationship services

Relationship services

Relationship services

Relationship services

Relationship services

Encounter services

Encounter services

Multiple settings

Multiple settings

Encounter services

Relationship services
B2B

B2B

B2C

B2C

B2B

B2C

$\mathrm{B} 2 \mathrm{~B}$

B2B

B2B

B2B

B2B

B2C

B2C

B2C

$\mathrm{B} 2 \mathrm{C}$

B2B

B2C

B2C Unpublished

B2C Published

B2C Unpublished

B2C Published

B2C Published

B2B Published

B2B Published

B2C Published

B2C Unpublished
Nonstudents

Nonstudents

Nonstudents

Nonstudents

Nonstudents

Nonstudents

Nonstudents

Nonstudents

Nonstudents

Nonstudents

Nonstudents

Nonstudents

Nonstudents

Nonstudents

Nonstudents

Nonstudents

Nonstudents

Nonstudents

Nonstudents

Nonstudents

Nonstudents

Nonstudents

Nonstudents

Nonstudents

Nonstudents

Nonstudents 
Salleh (2014)

Scanlan \& McPhail (2000)

Schakett et al. (2011)

Schumann et al. (2014)

Senders (2012), Senders et al. (2013)

Shammout \& Algharabat (2013)

Shammout et al. (2007)

Shanka \& Buvik (2019)

Shin et al. (2015)

Singh-Gaur et al. (2011)

Sirikit (2004)

Smith (1998)

Song \& Xu (2011)

Spake \& Megehee (2010)

Srihadi and Setiawan (2015; Dry cleaner)

Srihadi and Setiawan (2015; Hairdresser)

Srihadi and Setiawan (2015; Travel agent)

Su et al. (2009)

Suárez-Álvarez et al. (2004)

Sweeney \& Webb (2007)

Tai (2015)

Taleghani et al. (2011)

Tariq et al. (2014)

Terblanche (2013)

Tseng \& Lee (2018)

Vandeputte (2008; Study 1)

\begin{tabular}{|c|c|c|}
\hline 755 & - & $\checkmark$ \\
\hline 119 & $\checkmark$ & $\checkmark$ \\
\hline 88 & - & $\checkmark$ \\
\hline 1,995 & - & - \\
\hline 157 & $\checkmark$ & $\checkmark$ \\
\hline 319 & - & $\checkmark$ \\
\hline 451 & - & $\checkmark$ \\
\hline 159 & - & $\checkmark$ \\
\hline 363 & $\checkmark$ & $\checkmark$ \\
\hline 320 & $\checkmark$ & - \\
\hline 615 & $\checkmark$ & - \\
\hline 185 & - & $\checkmark$ \\
\hline 680 & $\checkmark$ & - \\
\hline 281 & - & $\checkmark$ \\
\hline 75 & $\checkmark$ & $\checkmark$ \\
\hline 75 & $\checkmark$ & $\checkmark$ \\
\hline 75 & $\checkmark$ & $\checkmark$ \\
\hline 394 & $\checkmark$ & $\checkmark$ \\
\hline 741 & - & - \\
\hline 275 & $\checkmark$ & $\checkmark$ \\
\hline 162 & - & - \\
\hline 384 & $\checkmark$ & $\checkmark$ \\
\hline 110 & - & $\checkmark$ \\
\hline 75 & - & - \\
\hline 303 & $\checkmark$ & - \\
\hline 199 & - & - \\
\hline
\end{tabular}

Relationship services

Encounter services

Relationship services

Relationship services

Relationship services

Relationship services

Encounter services

Relationship services

Encounter services

Relationship services

Encounter services

Multiple settings

Encounter services

Relationship services

Encounter services

Relationship services

Relationship services

Encounter services

Relationship services

Multiple settings

Encounter services

Relationship services

Relationship services

Relationship services

Relationship services

Encounter services

$\begin{array}{lcl}\text { B2C } & \text { Published } & \text { Nonstudents } \\ \text { B2C } & \text { Published } & \text { Nonstudents } \\ \text { B2B } & \text { Published } & \text { Nonstudents } \\ \text { B2C } & \text { Published } & \text { Nonstudents } \\ \text { B2C } & \text { Published } & \text { Nonstudents } \\ \text { B2C } & \text { Published } & \text { Nonstudents } \\ \text { B2C } & \text { Published } & \text { Nonstudents } \\ \text { B2B } & \text { Published } & \text { Nonstudents } \\ \text { B2C } & \text { Published } & \text { Nonstudents } \\ \text { B2C } & \text { Published } & \text { Nonstudents } \\ \text { B2C } & \text { Unpublished } & \text { Nonstudents } \\ \text { B2B } & \text { Published } & \text { Nonstudents } \\ \text { B2C } & \text { Unpublished } & \text { Nonstudents } \\ \text { B2C } & \text { Published } & \text { Nonstudents } \\ \text { B2C } & \text { Published } & \text { Nonstudents } \\ \text { B2C } & \text { Published } & \text { Nonstudents } \\ \text { B2C } & \text { Published } & \text { Nonstudents } \\ \text { B2C } & \text { Published } & \text { Nonstudents } \\ \text { B2C } & \text { Unpublished } & \text { Nonstudents } \\ \text { B2B } & \text { Published } & \text { Nonstudents } \\ \text { B2C } & \text { Published } & \text { Nonstudents } \\ \text { B2C } & \text { Published } & \text { Nonstudents } \\ \text { B2C } & \text { Published } & \text { Nonstudents } \\ \text { B2C } & \text { Published } & \text { Nonstudents } \\ \text { B2C } & \text { Published } & \text { Nonstudents } \\ \text { B2C } & \text { Unpublished } & \text { Nonstudents }\end{array}$


Vandeputte (2008; Study 2)

Varela-Neira et al. (2010)

Vazifeh-Doost \& Noorbakhsh (2015)

Virvilaite et al. (2009)

Vogel et al. (2008)

Wagner \& Benoit (2015)

Wai et al. (2012)

Wang (2008; Credit cards)

Wang (2008; Deposits)

Wang (2008; Loans)

Wang \& Hsu (2012)

Wang et al. (2005)

Wei et al. (2015; China)

Wei et al. (2015; France)

Wei et al. (2015; U.S.)

Weng et al. (2010)

Widiana (2013)

Williams et al. (1998; China)

Williams et al. (1998; Costa Rica)

Williams et al. (1998; Germany)

Williams et al. (1998; Jamaica)

Williams et al. (1998; U.S.)

Wu (2011; Beauty salon)

$\mathrm{Wu}$ (2011; Electronics retailer)

$\mathrm{Wu}$ (2011; Financial services)

$\mathrm{Xu}$ et al. (2006)

$\begin{array}{rrrr}199 & - & - & \checkmark \\ 344 & - & - & \checkmark \\ 120 & \checkmark & \checkmark & \checkmark \\ 112 & \checkmark & \checkmark & - \\ 5,694 & - & \checkmark & - \\ 527 & - & - & \checkmark \\ 200 & \checkmark & \checkmark & \checkmark \\ 216 & - & \checkmark & \checkmark \\ 431 & - & \checkmark & \checkmark \\ 396 & - & \checkmark & \checkmark \\ 424 & \checkmark & \checkmark & \checkmark \\ 307 & \checkmark & \checkmark & \checkmark \\ 160 & \checkmark & \checkmark & \checkmark \\ 168 & \checkmark & \checkmark & \checkmark \\ 174 & \checkmark & \checkmark & \checkmark \\ 403 & \checkmark & \checkmark & \checkmark \\ 180 & \checkmark & \checkmark & \checkmark \\ 25 & - & \checkmark & \checkmark \\ 40 & - & \checkmark & \checkmark \\ 31 & - & \checkmark & \checkmark \\ 54 & - & \checkmark & \checkmark \\ 129 & - & \checkmark & \checkmark \\ 145 & - & \checkmark & - \\ 172 & - & \checkmark & - \\ 129 & - & \checkmark & - \\ 476 & \checkmark & \checkmark & \checkmark\end{array}$

\section{Encounter services}

Encounter services

Relationship services

Relationship services

Relationship services

Encounter services

Relationship services

Encounter services

Encounter services

Relationship services

Encounter services

Multiple settings

Encounter services

Encounter services

Encounter services

Relationship services

Encounter services

Multiple settings

Multiple settings

Multiple settings

Multiple settings

Multiple settings

Relationship services

Encounter services

Relationship services

Relationship services
B2C Unpublished Nonstudents

B2C Unpublished Nonstudents

B2C Published Students

B2C Unpublished Students

B2C Published Nonstudents

B2B Published Nonstudents

B2C Unpublished Nonstudents

B2C Published Nonstudents

B2C Published Nonstudents

B2C Published Nonstudents

B2C Published Nonstudents

B2C Unpublished Nonstudents

B2C Published Students

B2C Published Students

B2C Published Students

B2C Published Nonstudents

B2C Published Nonstudents

B2B Published Nonstudents

B2B Published Nonstudents

B2B Published Nonstudents

B2B Published Nonstudents

B2B Published Nonstudents

B2C Published Nonstudents

B2C Published Nonstudents

B2C Published Nonstudents

B2C Published Nonstudents 
Yacout (2010)

Yang et al. (2018)

Yang et al. (2016)

Yen \& Barnes (2011)

Yen \& Gwinner (2003)

Yen et al. (2015)

Yu \& Tung (2013)

Yu et al. (2015)

Zhang et al. (2005)

Zhang et al. (2016)

$\begin{array}{ll}121 & \checkmark \\ 300 & - \\ 210 & - \\ 208 & - \\ 459 & \checkmark \\ 758 & \checkmark \\ 408 & - \\ 340 & - \\ 282 & - \\ 262 & \checkmark\end{array}$

Relationship services

Relationship services

Relationship services

Multiple settings

Encounter services

Relationship services

Relationship services

Encounter services

Multiple settings

Encounter services
B2C

$\mathrm{B} 2 \mathrm{C}$

$\mathrm{B} 2 \mathrm{C}$

$\mathrm{B} 2 \mathrm{~B}$

$\mathrm{B} 2 \mathrm{C}$

$\mathrm{B} 2 \mathrm{C}$

$\mathrm{B} 2 \mathrm{C}$

B2C

B2C

$\mathrm{B} 2 \mathrm{C}$
Published

Published

Published

Published

Published

Published

Published

Published

Unpublished

Published
Nonstudents

Nonstudents

Nonstudents

Nonstudents

Students

Nonstudents

Nonstudents

Nonstudents

Nonstudents

Nonstudents 
Web Appendix G: Results of the pairwise analyses

File-

\begin{tabular}{|c|c|c|c|c|c|c|c|c|c|}
\hline Relationship & & $\mathbf{k}$ & $\mathbf{N}$ & $\mathbf{r}_{\text {resw }}$ & S.E. & $\begin{array}{l}\text { C.I. } \\
\text { Lower }\end{array}$ & $\begin{array}{l}\text { C.I. } \\
\text { Upper }\end{array}$ & $\begin{array}{c}\text { drawer } \\
\mathbf{N}\end{array}$ & $\begin{array}{l}\text { Chi' }{ }^{2} \text { Test of } \\
\text { homogeneity }\end{array}$ \\
\hline \multirow{7}{*}{$\begin{array}{l}\text { Confidence } \\
\text { benefits } \leftrightarrow\end{array}$} & Social benefits & 60 & 24,474 & $0.51^{* * *}$ & 0.02 & 0.46 & 0.56 & 103,186 & $1449.66 * * *$ \\
\hline & Special treatment benefits & 67 & 27,328 & $0.52^{* * *}$ & 0.03 & 0.46 & 0.57 & 113,229 & $2068.24 * * *$ \\
\hline & Perceived value & 18 & 5,468 & $0.61^{* * *}$ & 0.04 & 0.53 & 0.70 & 11,628 & $435.23 * * *$ \\
\hline & Switching cost & 12 & 6,183 & $0.36^{* * *}$ & 0.08 & 0.19 & 0.52 & 3,137 & $460.97 * * *$ \\
\hline & Relationship quality & 91 & 31,567 & $0.65^{* * *}$ & 0.02 & 0.60 & 0.70 & 346,724 & $4769.89 * * *$ \\
\hline & Customer loyalty & 73 & 40,365 & $0.57^{* * *}$ & 0.03 & 0.51 & 0.63 & 195,298 & $3609.69 * * *$ \\
\hline & Firm sales performance & 11 & 6,075 & $0.46^{* * *}$ & 0.06 & 0.34 & 0.58 & 2,664 & $253.72 * * *$ \\
\hline \multirow{6}{*}{$\begin{array}{l}\text { Social } \\
\text { benefits } \leftrightarrow\end{array}$} & Special treatment benefits & 87 & 40,365 & $0.55^{* * *}$ & 0.03 & 0.49 & 0.62 & 361,946 & $6083.53 * * *$ \\
\hline & Perceived value & 17 & 16,296 & $0.56^{* * *}$ & 0.04 & 0.48 & 0.64 & 11,974 & $789.88 * * *$ \\
\hline & Switching cost & 10 & 5,852 & $0.33^{* * *}$ & 0.04 & 0.24 & 0.41 & 2,623 & $115.12 * * *$ \\
\hline & Relationship quality & 128 & 51,914 & $0.56^{* * *}$ & 0.02 & 0.52 & 0.60 & 447,209 & $4993.77 * * *$ \\
\hline & Customer loyalty & 90 & 45,273 & $0.47^{* * *}$ & 0.03 & 0.42 & 0.52 & 210,357 & $3407.91 * * *$ \\
\hline & Firm sales performance & 25 & 20,932 & $0.28^{* * *}$ & 0.04 & 0.20 & 0.35 & 8,821 & $643.83 * * *$ \\
\hline \multirow{5}{*}{$\begin{array}{l}\text { Special } \\
\text { treatment } \\
\text { benefits } \leftrightarrow\end{array}$} & Perceived value & 20 & 12,028 & $0.45^{* * *}$ & 0.04 & 0.37 & 0.53 & 9,615 & $562.46 * * *$ \\
\hline & Switching cost & 14 & 8,237 & $0.30^{* * *}$ & 0.08 & 0.14 & 0.46 & 4,154 & $637.49 * * *$ \\
\hline & Relationship quality & 141 & 54,421 & $0.49^{* * *}$ & 0.02 & 0.45 & 0.53 & 461,822 & $4892.85 * * *$ \\
\hline & Customer loyalty & 104 & 45,853 & $0.40^{* * *}$ & 0.02 & 0.36 & 0.44 & 200,037 & $2627.98 * * *$ \\
\hline & Firm sales performance & 30 & 18,536 & $0.21 * * *$ & 0.03 & 0.16 & 0.27 & 5,380 & $377.79 * * *$ \\
\hline \multirow{4}{*}{$\begin{array}{l}\text { Perceived } \\
\text { value } \leftrightarrow\end{array}$} & Switching cost & 6 & 4,147 & $0.30 * * *$ & 0.03 & 0.24 & 0.37 & 374 & $35.72 * * *$ \\
\hline & Relationship quality & 20 & 12,896 & $0.76^{* * *}$ & 0.03 & 0.71 & 0.81 & 31,189 & $1946.45 * * *$ \\
\hline & Customer loyalty & 23 & 15,159 & $0.61^{* * *}$ & 0.04 & 0.52 & 0.69 & 31,739 & $1633.81 * * *$ \\
\hline & Firm sales performance & 9 & 9,883 & $0.36^{* * *}$ & 0.03 & 0.30 & 0.42 & 2,084 & $137.18 * * *$ \\
\hline \multirow{3}{*}{$\begin{array}{l}\text { Switching } \\
\text { costs } \leftrightarrow\end{array}$} & Relationship quality & 14 & 6,820 & $0.39^{* * *}$ & 0.07 & 0.26 & 0.52 & 3,604 & $407.12 * * *$ \\
\hline & Customer loyalty & 16 & 7,179 & $0.39 * * *$ & 0.04 & 0.31 & 0.47 & 3,910 & $239.56 * * *$ \\
\hline & Firm sales performance & 7 & 4,737 & $0.35 * * *$ & 0.05 & 0.26 & 0.44 & 748 & $75.02 * * *$ \\
\hline \multirow{2}{*}{$\begin{array}{l}\text { Relationship } \\
\text { quality } \leftrightarrow\end{array}$} & Customer loyalty & 96 & 39,597 & $0.71 * * *$ & 0.02 & 0.67 & 0.76 & 525,494 & $8316.81 * * *$ \\
\hline & Firm sales performance & 32 & 17,957 & $0.52 * * *$ & 0.05 & 0.43 & 0.61 & 30,289 & $1600.37 * * *$ \\
\hline Customer & Firm sales performance & 21 & 18,045 & $0.60 * * *$ & 0.05 & 0.49 & 0.70 & 2,879 & $1711.99 * * *$ \\
\hline
\end{tabular}

Notes: $* * * p<.001,{ }^{\text {n.s. }}$ Not significant. rrsw $_{\text {r }}$ Reliability-corrected sample size-weighted correlation, S.E. $=$ Standard error, C.I. $=$ Confidence Interval. One-tailed tests of significance. All statistics (effect sizes, standard errors, confidence intervals, homogeneity tests) are calculated using Hunter and Schmidt's (2004) formulae. The File-drawer N is calculated using Rosenthal's (1979) formula. 


\section{Web Appendix H: Average levels of relational benefits}

All 235 independent samples were coded for the average levels and standard deviations of confidence benefits, social benefits, and special treatment benefits. Only about one-third of studies reported this information. Given the differences in number of scale points used to measure relational benefits across the different studies (mostly a five-point or a seven-point scale), we recalibrated all means and standard deviations onto a 0-100 scale. We also calculated (i) standard error of means by dividing the standard deviation reported in a study by the square root of the sample size of that study and (ii) $95 \%$ confidence intervals around the mean. The table below reports the summary statistics.

\begin{tabular}{lccc} 
& $\begin{array}{c}\text { Confidence } \\
\text { benefits }\end{array}$ & $\begin{array}{c}\text { Social } \\
\text { benefits }\end{array}$ & $\begin{array}{c}\text { Special } \\
\text { treatment } \\
\text { benefits }\end{array}$ \\
\hline Mean & 67 & 51 & 49 \\
Standard deviation & $(61)$ & $(92)$ & $(93)$ \\
Standard error & 16 & 19 & 18 \\
Confidence intervals & $(48)$ & $(79)$ & $(80)$ \\
& .92 & 1.21 & 1.05 \\
\hline
\end{tabular}

Note: Numbers between parentheses refer to the number of means we could extract from the 235 samples.

Customers perceive higher levels of confidence benefits (67) than social benefits and special treatment benefits (49). This difference appears significant, as the confidence intervals for confidence benefits do not overlap with the confidence intervals for social and special treatment benefits. Overlapping confidence intervals suggest that, overall, customers perceive an equal level of social benefits and special treatment benefits.

We also examined whether the average levels of relational benefits might differ across contexts. We ran independent-samples t-tests using the recalibrated levels of relational benefits as dependent variables. The results are listed below.

\begin{tabular}{lccc} 
Confidence & $\begin{array}{c}\text { Social } \\
\text { benefits }\end{array}$ & $\begin{array}{c}\text { Special } \\
\text { benefits }\end{array}$ & $\begin{array}{c}\text { treatment } \\
\text { benefits }\end{array}$ \\
\hline B2B & 64 & 56 & 55 \\
B2C & 68 & 50 & 48 \\
$t$-value & $0.972^{\text {n.s. }}$ & $1.620^{\text {n.s. }}$ & $1.534^{\text {n.s. }}$ \\
$d f$ & 59 & 90 & 91 \\
\hline Encounter services & 65 & 48 & 47 \\
Relationship services & 69 & 57 & 55 \\
$t$-value & $1.263^{\text {n.s. }}$ & $2.404^{*}$ & $1.929^{+}$ \\
$d f$ & $52^{*}$ & 77 & 77 \\
\hline
\end{tabular}


The t-tests reveal that the average level of the three relational benefits does not differ significantly between $\mathrm{B} 2 \mathrm{~B}$ and $\mathrm{B} 2 \mathrm{C}$ contexts (all $p$-values $>.10$ ). The average level of confidence benefits does not differ between encounter and relationship services $(p>.10)$. The average level of social benefits is significantly higher in relationship services (57) than in encounter services $(48 ; t(77)=2.404, p<.05)$. The average level of special treatment benefits is marginally significantly higher in relationship services (55) than in encounter services (47; $t(77)=1.929, p<.06)$. These findings suggest that the level of relational benefits is very similar for different types of services. 